\title{
Exploring Virulence Factors and Alternative Therapies against Staphylococcus aureus Pneumonia
}

\author{
Jelle Vlaeminck ${ }^{1, \dagger}$, Dina Raafat ${ }^{2,3,+} \oplus$, Kristin Surmann ${ }^{4}$, Leen Timbermont ${ }^{1}($, \\ Nicole Normann ${ }^{2}{ }^{1}$, Bret Sellman ${ }^{5}$, Willem J. B. van Wamel ${ }^{6}$ and Surbhi Malhotra-Kumar ${ }^{1, *}$ \\ 1 Laboratory of Medical Microbiology, Vaccine and Infectious Diseases Institute, University of Antwerp, \\ 2610 Antwerp, Belgium; Jelle.Vlaeminck@uantwerpen.be (J.V.); leen.timbermont@uantwerpen.be (L.T.) \\ 2 Department of Immunology, Institute of Immunology and Transfusion Medicine, University Medicine \\ Greifswald, 17475 Greifswald, Germany; dina.raafat@med.uni-greifswald.de (D.R.); \\ Nicole.Normann@med.uni-greifswald.de (N.N.) \\ 3 Department of Microbiology and Immunology, Faculty of Pharmacy, Alexandria University, \\ Alexandria 21521, Egypt \\ 4 Department of Functional Genomics, Interfaculty Institute for Genetics and Functional Genomics, \\ University Medicine Greifswald, 17475 Greifswald, Germany; kristin.surmann@uni-greifswald.de \\ 5 Microbiome Discovery, Microbial Sciences, BioPharmaceuticals R \& D, AstraZeneca, \\ Gaithersburg, MD 20878, USA; bret.sellman@astrazeneca.com \\ 6 Department of Medical Microbiology and Infectious Diseases, Erasmus Medical Center Rotterdam, \\ 3015 Rotterdam, The Netherlands; w.vanwamel@erasmusmc.nl \\ * Correspondence: surbhi.malhotra@uantwerpen.be; Tel.: +32-3-265-27-52 \\ + These authors contributed equally to this work.
}

Received: 19 October 2020; Accepted: 15 November 2020; Published: 18 November 2020

\begin{abstract}
Pneumonia is an acute pulmonary infection associated with high mortality and an immense financial burden on healthcare systems. Staphylococcus aureus is an opportunistic pathogen capable of inducing S. aureus pneumonia (SAP), with some lineages also showing multidrug resistance. Given the high level of antibiotic resistance, much research has been focused on targeting S. aureus virulence factors, including toxins and biofilm-associated proteins, in an attempt to develop effective SAP therapeutics. Despite several promising leads, many hurdles still remain for $S$. aureus vaccine research. Here, we review the state-of-the-art SAP therapeutics, highlight their pitfalls, and discuss alternative approaches of potential significance and future perspectives.
\end{abstract}

Keywords: Staphylococcus aureus; pneumonia; virulence; therapeutics

Key Contribution: S. aureus pneumonia is associated with high fatality and a large array of virulence factors. This review offers an in-depth analysis of the development of non-antibiotic alternatives against $S$. aureus pneumonia.

\section{Introduction}

Pneumonia is one of the leading causes of death in developed countries, with up to 2.56 million recorded fatalities in 2017 [1]. Its immense impact on healthcare is even more pronounced among young children, where it accounts for $15 \%$ of all fatalities in children below five years of age [2]. Data from the United Nations Children's Fund (UNICEF) estimates that every 39 s, a child succumbs to pneumonia [3]. Pneumonia is defined as an acute infection of the lung parenchyma caused by one or several co-infecting pathogens, which can be of fungal, viral, or bacterial origin $[4,5]$. In this review, we focus on bacterial pneumonia, where severe episodes are associated with high mortality rates, reaching up to $22 \%$ among ICU patients (all common pathogens) [6]. 
Based on the presumed origin of the pathogen, episodes of pneumonia are generally classified into four types that are sometimes difficult to differentiate: (i) hospital-associated pneumonia (HAP), constituting about $20 \%$ of all nosocomial infection [7], with an onset later than $48 \mathrm{~h}$ after hospital admission; (ii) ventilator-associated pneumonia (VAP), occurring after more than $48 \mathrm{~h}$ following intubation; (iii) community-associated pneumonia (CAP), with an onset before or within the first $48 \mathrm{~h}$ post-admission [8,9]; and (iv) health-care-associated pneumonia (HCAP), occurring in patients coming from high-risk environments such as nursing homes and extended-care facilities, in patients receiving long term care (e.g., dialysis), or patients who had undergone recent hospitalization prior to the current hospital admission [10]. CAP is the most common type of pneumonia and is commonly caused by Streptococcus pneumoniae, although other pathogens, both Gram-positive and Gram-negative, might also be involved [11] (Table 1).

Table 1. Pathogens commonly encountered in the different types of bacterial pneumonia.

\begin{tabular}{|c|c|c|c|}
\hline Class & $\mathrm{CAP}^{(\mathrm{a})}[11-13]$ & HAP/VAP $[11,14]$ & HCAP [12,15] \\
\hline Gram-positive & $\begin{array}{l}\text { Streptococcus pneumoniae } \\
\text { Staphylococcus aureus }\end{array}$ & $\begin{array}{l}\text { Streptococcus pneumoniae } \\
\text { Streptococcus spp. } \\
\text { Staphylococcus aureus }\end{array}$ & $\begin{array}{l}\text { Streptococcus pneumoniae } \\
\text { Staphylococcus aureus }^{(b)}\end{array}$ \\
\hline Gram-negative & $\begin{array}{c}\text { Mycoplasma pneumoniae } \\
\text { Chlamydophila pneumoniae } \\
\text { Haemophilus influenzae } \\
\text { Legionella spp. } \\
\text { Pseudomonas aeruginosa } \\
\text { Enterobacteriaceae } \\
\text { (Escherichia coli, Klebsiella } \\
\text { spp., Enterobacter spp., } \\
\text { Proteus mirabilis) }\end{array}$ & $\begin{array}{c}\text { Enterobacteriaceae } \\
\text { (Escherichia coli, Klebsiella } \\
\text { spp., Enterobacter spp., } \\
\text { Proteus spp.) } \\
\text { Serratia marcescens } \\
\text { Pseudomonas aeruginosa } \\
\text { Acinetobacter spp. } \\
\text { Haemophilus influenza } \\
\text { Stenotrophomonas maltophilia }\end{array}$ & $\begin{array}{c}\text { Haemophilus influenzae } \\
\text { Pseudomonas aeruginosa } \\
\text { Acinetobacter baumannii } \\
\text { Stenotrophomonas maltophilia }\end{array}$ \\
\hline
\end{tabular}

spp.: species; ${ }^{(a)}$ pathogen identification fails in about $50 \%$ of cases [16]; ${ }^{(b)}$ both methicillin-resistant (MRSA) and methicillin-sensitive $S$. aureus (MSSA).

\section{Staphylococcus aureus Pneumonia}

Staphylococcus aureus is a rare CAP-causing pathogen, as was shown by a longitudinal study involving nearly 10 million pneumonia cases requiring hospitalization, where in only $1.08 \%$ of the cases, S. aureus pneumonia (SAP) was identified as the primary diagnosis [17]. In HAP and VAP, $S$. aureus has a more prominent role as the pathology differs from CAP; the importance of $S$. aureus as a pneumonia pathogen was recently demonstrated in the ASPIRE-ICU observational trial [18]. However, despite a low prevalence in CAP, SAP, in general, is linked to a high case-fatality rate, ranging from $48 \%$ to $84 \%$ [19-21]. A recent retrospective analysis of 98 SAP patients admitted to a Spanish hospital between the years 2000 and 2014 revealed a 30-day mortality rate of 46.9\% [22]. Also, SAP was recently identified as an important part of complications and mortality in SARS-CoV-2 patients [23]. This situation is even more complicated by the multidrug-resistant character of $S$. aureus. The longitudinal study of Jacobs et al. also showed that, of those above-mentioned patients hospitalized with SAP, approximately $78 \%$ of the cases were attributed to methicillin-resistant $S$. aureus (MRSA) [17]. MRSA clones harbor the staphylococcal cassette chromosome mec (SCCmec), a mobile genetic element conferring resistance to cefoxitin and many other $\beta$-lactam antibiotics [24]. Initially, pulmonary infections with MRSA were limited to HAP and VAP, and hence arose the term hospital-associated MRSA (HA-MRSA), such as the HA-MRSA sequence type (ST)239 lineage [25]. However, in the last two decades, there has been a surge in community-associated MRSA (CA-MRSA), which, in turn, is associated with CAP [26]. CA-MRSA infections became increasingly prevalent due to the global spread of highly virulent clones such as the USA300 (ST8) [27]. However, the distinction between HAP and CAP based on the causative clone has become increasingly difficult, since several CA-MRSA clones have been observed to cause nosocomial infections $[9,28,29]$. 
Apart from certain representative clones, HA- and CA-MRSA strains can be distinguished by specific molecular characteristics [28], for instance, by the type of SCCmec they carry. While HA-MRSA typically harbor the larger SCCmec types I, II, and III, CA-MRSA carry the smaller SCCmec types IV and V $[28,30,31]$. SCCmec also allows for the integration of other resistance-conferring genes into the three adjoining regions of the element $[30,31]$. Examples are (i) $\operatorname{Tet} \mathrm{A}(\mathrm{K})$ and $\operatorname{Tet} \mathrm{A}(\mathrm{L})$ efflux pumps, conveying resistance to tetracyclines whose genes have integrated in the SCCmec III cassette and (ii) integration of aminoglycosides resistance genes aacA-aphD in SCCmec II [32,33]. Such molecular events were largely responsible for the significant surge in multidrug-resistant $S$. aureus clones over the last decades. On the other hand, while CA-MRSA strains are susceptible to more antibiotic classes, they are more virulent due to the higher abundance of virulence factors, such as Panton-Valentine leukocidin (PVL), and a higher expression of core virulence factors [34,35]. Given the high levels of multidrug resistance, alternative anti-infective therapeutics have recently garnered much attention, in the hope of combating $S$. aureus. This review will therefore include a comprehensive overview of S. aureus virulence factors that have been targeted in search of an effective SAP vaccine, as well as outline some alternative therapeutic approaches that may hold promise for $S$. aureus research.

SAP occurs when the bacterium gains access to the epithelial cells of the upper airway due to damage of the mucosal lining, which can be facilitated by viral infections such as influenza and measles [36,37] or by the insertion of an endotracheal tube for mechanical ventilation. This exposure subsequently leads to the activation of the host's proinflammatory innate immune response, with immune cell activation as well as neutrophil and macrophage recruitment (reviewed in [38]). The increased neutrophil influx into the lungs, accompanied by their secreted granular toxins, contributes to the lung pathology during SAP, by causing inflammation and necrosis of the lung epithelial cells [39-41]. Furthermore, the adaptive immune response further exacerbates the lung pathology. Indeed, a study in mice lacking $\mathrm{CD} 4^{+} \mathrm{T}$ cells showed improved bacterial clearance during SAP [39]. The complex interplay between $S$. aureus and the adaptive immune response is reviewed in [42], while the immunopathogenesis during pneumonia is reviewed in [43]. Apart from the role of the immune response, the contact between S. aureus and the upper airway epithelial cells is also believed to cause an upregulation of the bacterial virulence factors [44]. These virulence factors serve various functions, including cell lysis through lytic toxins, immune modulation as well as biofilm formation since several $S$. aureus clones have been identified as prolific biofilm formers, adding to the pathology [45]. Given their importance in SAP pathogenesis, which in turn is linked to a high case-mortality rate, those virulence factors, together with their molecular detection and potential as a therapeutic target, are the focus of this review.

S. aureus is known to express a large number of virulence factors, ranging from adhesins to toxins to immune evasion proteins, and hence, targeting these factors has been the focus of modern anti-S. aureus therapy $[46,47]$. Several virulence factors of S. aureus have been studied in the context of pneumonia. The aim of researchers was to find a suitable antigen with the following characteristics: (i) is relevant to S. aureus pathogenesis in pneumonia; (ii) is conserved in many S. aureus strains; (iii) can elicit a protective immune response; and (iv) shows promising results both in vitro and in vivo in several pneumonia models.

\section{Contribution of OMICs Techniques to SAP Research}

Modern OMICs technologies have provided multiple tools to extensively research SAP and its relevant virulence factors. 


\subsection{Genomics}

With the introduction of the whole genome sequencing (WGS) technology in the field of clinical microbiology, more information became available on $S$. aureus and its virulence factors. The first two S. aureus genomes were sequenced in 2001 by Kuroda et al., which provided completely new insights into the genomic background of this pathogen [48]. These and future studies revealed that the core genome is quite conserved across the $S$. aureus species, with variations mostly being attributed to mobile genetic elements such as transposons, insertion sequence elements, SCCmec, etc. Shortly after the Kuroda et al. study [48], the sequenced genome of S. aureus MW2 revealed that it harbored the $l u k F$ and $l u k S$ genes, encoding the highly potent PVL, on a prophage element integrated into the genome [49]. Over the next two decades, large-scale sequencing projects shed light on HA-MRSA and their high level of antibiotic resistance, the dynamics of CA-MRSA and the impact of horizontal gene transfer (reviewed in $[35,50,51]$ ). S. aureus genomics has been extensively reviewed $[52,53]$.

\subsection{Proteomics}

Proteomics provided a valuable tool to understand the interactions of an infected host with the pathogen, helping to refine and further focus on virulence factors unexpressed in the early phases of the disease. A mass spectrometry experiment typically provides quantitative data of host and pathogen proteins and have been, until now, mostly performed in simple cell culture models using human lung cell lines to simulate single events during SAP [54-56]. Analysis of S. aureus proteins within a background of prevalent human proteins in in vivo samples remains, however, challenging. Nevertheless, in vivo studies already provided interesting results. For instance, in a murine S. aureus pneumonia model, host proteins found to be associated with infection included extracellular matrix proteins, as well as intracellular proteins such as phagosomal proteins and hemoglobin [57]. Another preliminary study, investigating $S$. aureus-influenza co-infection, reported distinct differences in host protein abundance levels, observed by two-dimensional difference gel electrophoresis (2D-DIGE), for about 200 proteins between co-infection or single-infection groups as well as non-infected control samples [58]. A global analysis of in vivo proteome adaptation of $S$. aureus in a mouse pneumonia model showed increased abundance of glycolysis-, amino acid biosynthesis- and fermentation-related proteins as well as virulence factors mediating oxidative stress response [56].

\subsection{Metabolomics}

Not only proteins but also metabolites are affected during infection, since the host and the pathogen need to share the intracellular resources. In a cell culture study, glucose and almost all amino acids were found inside the host cells at the time of infection [54]. In agreement with this observation, increased levels of proteins involved in bacterial glycolysis during the course of an infection reflect the consumption of this intracellular carbon source. Metabolomic analyses have been successfully employed to discover specific biomarkers that can distinguish CAP from other lung infections. Compared to patients suffering from chronic obstructive pulmonary disease (COPD), fewer phospholipids were found in the plasma of CAP patients [59]. More interestingly, metabolomics allows for the differentiation of pneumonia-causing pathogens. For instance, SAP is distinguishable from S. pneumoniae-induced pneumonia based on the host's metabolite patterns [60]. Moreover, 25-fold lower concentrations of seven metabolites were observed in patients suffering from influenza-induced pneumonia compared to MRSA pneumonia [61]. In this review, we analyze potential targets, some of which are currently under development as potential therapeutics that have resulted from recent genomic, proteomic, and metabolomics studies (Table 2). 


\section{Targeting Virulence Factors Associated with Biofilms}

An important factor that further adds to S. aureus pathology is the formation of biofilms [45]. A biofilm is defined as a microbially derived, sessile community embedded into an extracellular matrix, usually consisting of polysaccharides, proteins, nucleic acids and lipids [62-64]. It attaches to both biological (e.g., lung, intestine, heart valve, and tooth) as well as abiological surfaces, such as indwelling medical devices (e.g., catheters, implants). Biofilms have been implicated in various persistent human microbial infectious diseases, ranging from dental caries and periodontitis, to endocarditis, urinary tract infections, osteomyelitis, respiratory infections in cystic fibrosis patients, and ICU pneumonia [65]. This alternative phenotype is beneficial to bacteria since it allows them to evade multiple clearance mechanisms, such as antimicrobials and the host immune system, leading to treatment failure and recurrent/chronic infections $[62,66]$. S. aureus biofilm production and virulence are closely linked, since the main biofilm regulator, the accessory gene regulator Agr, is also vital for the expression of numerous virulence factors [67]. Several virulence factors are known to accumulate in in vivo S. aureus biofilms [68-70], and are thought to contribute to the structural integrity of the extracellular matrix [71]. Therefore, many of the biofilm-related virulence factors have been the target of research on $S$. aureus therapeutics (Table 2). 
Table 2. Summary of virulence factors explored as potential targets for S. aureus pneumonia therapeutics.

\begin{tabular}{|c|c|c|c|c|c|c|c|}
\hline Targeted in SAP & Virulence Factor & Research Stage $^{\text {a }}$ & Approach/Strategy & Main Results & Advantages of Targeting $b$ & $\begin{array}{l}\text { Disadvantages of } \\
\text { Targeting } b\end{array}$ & References \\
\hline \multirow{6}{*}{ Yes } & \multirow[t]{2}{*}{ Hla } & PC & $\begin{array}{l}\text { in vitro: tissue cultures } \\
\text { in vivo: murine, rabbit, } \\
\text { and ferret models }\end{array}$ & $\begin{array}{l}\text { Protective potential of } \\
\text { passive and } \\
\text { active immunization }\end{array}$ & \multirow{2}{*}{$\begin{array}{l}\text { Core virulence factor; crucial } \\
\text { role in SAP }\end{array}$} & \multirow{2}{*}{$\begin{array}{l}\text { Complex } \\
\text { regulation }\end{array}$} & \multirow[t]{2}{*}[69,72-81]{} \\
\hline & & $\mathrm{C}$ & Human clinical trials & $\begin{array}{l}\text { Protective potential of } \\
\text { passive immunization }\end{array}$ & & & \\
\hline & $\mathrm{Hlb} / \mathrm{Hlg}$ & PC & $\begin{array}{l}\text { in vivo: murine } \\
\text { SAP model }\end{array}$ & $\begin{array}{l}\text { Hlb-deficient } \text { S. aureus } \\
\text { shows less severe } \\
\text { histopathology }\end{array}$ & $\begin{array}{l}\text { Prevalent in nearly all S. aureus } \\
\text { lineages; distinct role } \\
\text { in pathogenesis }\end{array}$ & NA & [82] \\
\hline & PSMs & PC & $\begin{array}{l}\text { in vivo: murine } \\
\text { SAP model }\end{array}$ & $\begin{array}{l}\text { Reduced mouse mortality } \\
\text { by indirect targeting } \\
\text { (blocking Agr system) }\end{array}$ & Distinct role in SAP & $\begin{array}{l}\text { Neutrophils are } \\
\text { more protected } \\
\text { than macrophages }\end{array}$ & [83] \\
\hline & SasX & PC & $\begin{array}{l}\text { in vitro: cell culture; } \\
\text { vaccination studies in } \\
\text { mice (skin abscess and } \\
\text { lung infection model) }\end{array}$ & $\begin{array}{l}\text { Induction of } \\
\text { antigen-specific IgG } \\
\text { response; protection from } \\
\text { S. aureus-induced } \\
\text { infection and colonization }\end{array}$ & $\begin{array}{l}\text { (i) active immunization induced } \\
\text { IgG1 response and reduced } \\
\text { acute lung injury; (ii) active and } \\
\text { passive immunization reduced } \\
\text { S. aureus colonization; } \\
\text { (iii) anti-SasX IgG increased } \\
\text { S. aureus killing by } \\
\text { human neutrophils }\end{array}$ & NK & [84] \\
\hline & Srt & PC & $\begin{array}{l}\text { in vitro: cell culture } \\
\text { in vivo: murine } S . \\
\text { aureus lung } \\
\text { infection models }\end{array}$ & $\begin{array}{l}\text { Deletion of SrtB reduced } \\
\text { mortality; reduced } \\
\text { S.aureus adhesion to } \\
\text { human lung } \\
\text { epithelial cells }\end{array}$ & $\begin{array}{l}\text { Anti-inflammatory effects } \\
\text { on macrophage }\end{array}$ & NK & [85] \\
\hline Yes & PVL & $\mathrm{PC}$ & $\begin{array}{l}\text { in vitro: } \\
\text { polymorphonuclear } \\
\text { leukocytes in vivo: } \\
\text { rabbit SAP, murine } \\
\text { sepsis models }\end{array}$ & $\begin{array}{l}\text { Neutralization of } \\
\text { cytotoxic effects (IVIG); } \\
\text { protective immunity }\end{array}$ & $\begin{array}{l}\text { Important role in pathogenesis } \\
\text { of necrotizing pneumonia }\end{array}$ & Low prevalence & [86-89] \\
\hline & SEVs & PC & $\begin{array}{l}\text { in vivo: murine models } \\
\text { (SAP, systemic infection, } \\
\text { skin infection, sepsis) }\end{array}$ & $\begin{array}{l}\text { Induction of } \\
\text { protective immunity }\end{array}$ & $\begin{array}{l}\text { Nano-size; safety profile; } \\
\text { multivalent nature; longer } \\
\text { persistence in host; induction of } \\
\text { innate/adaptive immune } \\
\text { response; intrinsic adjuvanticity }\end{array}$ & $\begin{array}{c}\text { Insufficient } \\
\text { humoral response } \\
\text { (reason for failure } \\
\text { of passive } \\
\text { immunization) } \\
\end{array}$ & [90-93] \\
\hline
\end{tabular}


Table 2. Cont.

\begin{tabular}{|c|c|c|c|c|c|c|c|}
\hline Targeted in SAP & Virulence Factor & Research Stage $^{\text {a }}$ & Approach/Strategy & Main Results & Advantages of Targeting ${ }^{b}$ & $\begin{array}{l}\text { Disadvantages of } \\
\text { Targeting } b\end{array}$ & References \\
\hline \multirow{5}{*}{ No } & LTA & PC & $\begin{array}{l}\text { in vitro: cell cultures; } \\
\text { in vivo: healthy humans }\end{array}$ & $\begin{array}{l}\text { Neutrophil recruitment; } \\
\text { proinflammatory; } \\
\text { pro-apoptotic effects } \\
\text { on macrophages; } \\
\text { affects hemostasis }\end{array}$ & Crucial S. aureus component & $\begin{array}{c}\text { Weak } \\
\text { immunogenicity }\end{array}$ & [94-97] \\
\hline & SpA & PC & $\begin{array}{l}\text { in vivo: murine models } \\
\text { (skin abscess, sepsis) }\end{array}$ & $\begin{array}{l}\text { Induction of protective } \\
\text { immunity against } S \text {. } \\
\text { aureus-induced infection }\end{array}$ & \multirow{2}{*}{$\begin{array}{l}\text { Induction of antigen-specific } \\
\text { IgG response; protection from } \\
\text { abscess formation and neonatal } \\
\text { sepsis in mice; prevention of } S \text {. } \\
\text { aureus colonization }\end{array}$} & \multirow{2}{*}{$\begin{array}{l}\text { Unexplored as } \\
\text { single target }\end{array}$} & \multirow{2}{*}{ [98-102] } \\
\hline & & $\mathrm{C}$ & $\begin{array}{l}\text { Vaccination study in } \\
\text { human (S. aureus } \\
\text { bacteremia) }\end{array}$ & $\begin{array}{l}\text { Good safety profile and } \\
\text { minimal side effects } \\
\text { in patients }\end{array}$ & & & \\
\hline & FnBPA & PC & $\begin{array}{l}\text { in vitro: cell culture } \\
\text { in vivo: vaccination } \\
\text { studies in mice } \\
\text { (FnBPA/SpA bivalent } \\
\text { fusion vaccine; murine } \\
\text { pneumonia and } \\
\text { bacteremia model) }\end{array}$ & $\begin{array}{l}\text { Induction of protective } \\
\text { immunity against } S \text {. } \\
\text { aureus-induced infections; } \\
\text { induction of } S . \text { aureus } \\
\text { killing by neutrophils }\end{array}$ & $\begin{array}{l}\text { Bivalent vaccine more } \\
\text { promising than SpA alone }\end{array}$ & $\begin{array}{l}\text { Unexplored as } \\
\text { single target }\end{array}$ & [103] \\
\hline & Fur & PC & $\begin{array}{l}\text { in vivo: murine SAP } \\
\text { model }\end{array}$ & $\begin{array}{l}\text { S. aureus lacking Fur is } \\
\text { less virulent and } \\
\text { protected against killing } \\
\text { by neutrophils }\end{array}$ & $\begin{array}{c}\text { Regulates several } \\
\text { immunomodulatory proteins }\end{array}$ & Not yet targeted & [104] \\
\hline \multirow{2}{*}{ No } & LukAB & PC & $\begin{array}{l}\text { in vitro: cell cultures } \\
\text { in vivo: murine } \\
\text { immunization (sepsis) }\end{array}$ & $\begin{array}{l}\text { Neutralization of } \\
\text { cytotoxicity; prevention of } \\
\text { cell lysis }\end{array}$ & $\begin{array}{l}\text { Main contributor in human } \\
\text { phagocyte killing }\end{array}$ & Not well described & [105-107] \\
\hline & LukED & PC & in vitro: cell cultures & $\begin{array}{l}\text { Induction of partial } \\
\text { resistance to killing; } \\
\text { functional inhibition } \\
\text { of LukED }\end{array}$ & $\begin{array}{l}\text { Highly conserved in epidemic } \\
\text { MRSA lineages }\end{array}$ & NK & [108] \\
\hline
\end{tabular}




\subsection{Haemolysins}

\subsubsection{Alpha-Toxin (Hla)}

Alpha toxin, also known as alpha-hemolysin (Hla), is a well-studied cytolytic protein. It is a member of the pore-forming beta-barrel toxin family and is encoded by the hla gene, which is one of the few virulence genes integrated into the core genome [109-113]. Hla lyses a plethora of cells including erythrocytes, epithelial cells, endothelial cells, T cells, monocytes, macrophages, and neutrophils. It can also stimulate a hyperinflammatory response, and disrupt epithelial and endothelial barriers, even at sublytic levels [110,114]. The importance of Hla as a virulence factor in SAP has been researched in mouse, rabbit and ferret pneumonia models [72,85,86,115], with studies reporting a disruptive effect on the air-blood barrier [116]. Moreover, isogenic hla mutants consistently demonstrated reduced infection severity compared to their wild type strains $[85,114,117]$.

Apart from its role as a cytolytic protein, Hla also promotes biofilm formation, and hence plays an essential role during biofilm-associated infections, both at the attachment as well as the cell-cell binding stage $[118,119]$. Despite the specific pathways still being unclear, the importance of Hla in biofilm-related $S$. aureus pathogenesis was demonstrated in different models using human skin and porcine vaginal mucosal tissue [69,73], as well as using transcriptomic approaches [120]. The generation of high titers of natural antibodies (Abs) against Hla following invasive S. aureus infections, including pneumonia, further confirms these findings [103,121,122].

Because of its importance in S. aureus pathogenesis and SAP, Hla is often targeted as a treatment strategy. Hence, the protective potential of several anti-Hla Abs (e.g., ASN100, LC10) against pneumonia was tested in rabbit, murine, and ferret pneumonia models, where active as well as passive immunization showed promising results [72,74-78]. Recently, there have been several human trials evaluating the potential use of passive immunization with anti-Hla Abs in the protection against SAP. These trials involved anti-Hla monoclonal Abs (mAbs), such as suvratoxumab (AstraZeneca, Cambridge, United Kingdom) [79], AR-301 (Aridis Pharmaceuticals, San Jose, CA, United States) [80], and the multivalent antitoxin ASN100 (Arsanis, Inc., Waltham, MA, United States) that targets five different S. aureus pore-forming toxins ("7. Multicomponent vaccines") [81]. Despite the fact that results from these trials did not reach statistical significance, passive immunization did show protective potential. For instance, AR-301 reduced the time spent on mechanical ventilation, whereas suvratoxumab reduced hospital and ICU duration as well as the duration of antibiotic treatment, while being safe and well-tolerated [79-81]. Apart from these mAbs, some natural compounds targeting Hla might provide a useful alternative for the prevention and/or treatment of SAP. These include the following: (i) a modified $\beta$-cyclodextrin compound, IB201, which was discovered based on its spatial similarity to Hla, and hence the hypothesis that it would block Hla activity with a high affinity [123]; (ii) bioflavonoid morin hydrate [124]; (iii) aloe-emodin, an active compound from aloe vera [125], and (iv) apigenin, an active compound from parsley [126]. All of these aforementioned compounds demonstrated adequate protection in murine SAP models [115,124-126].

\subsubsection{Beta- and Gamma-Toxin (Hlb \& Hlg)}

Other well-known toxins of $S$. aureus are beta-toxin (Hlb), a sphingomyelinase, and gamma-toxin $(\mathrm{Hlg})$, a leukocidin present in nearly all S. aureus lineages. Leukocidins are a set of $\beta$-barrel pore-forming toxins, capable of targeting erythrocytes, endothelial cells and host immune cells, thus helping S. aureus to evade the immune system and induce an inflammatory response [127]. Both Hla and Hlb are prevalent among nearly all $S$. aureus lineages and have a distinct role in S. aureus biofilm formation and pathogenesis [69,128-130]. Research on the contribution of Hlb and Hlg to SAP cytopathology is scarce, and their overall role in S. aureus diseases is still poorly understood [131]. One study showed that mice infected with Hlb-deficient $S$. aureus exhibited less severe histopathological signs of pneumonia, including reduced levels of neutrophilic inflammation, vascular leakage and protein exudation [82]. 
Some multivalent, Hlg neutralizing Abs have been developed, and will be discussed later under "7. Multicomponent vaccines".

\subsection{Phenol-Soluble Modulins (PSMs)}

Phenol-soluble modulins (PSMs) are comprised of seven amphipathic, $\alpha$-helical peptides, namely PSM $\alpha 1-\alpha 4$, PSM $\beta 1-\beta 2$, and the $S$. aureus delta-toxin, which are widespread among staphylococci [132-134]. PSMs are under direct control of the Agr quorum-sensing system, and they facilitate epithelial colonization and biofilm formation due to their surfactant properties [133]. Using a nonspecific, receptor-independent mechanism, and at micromolar concentrations, PSMs (especially PSM $\alpha$ ) enable the escape of $S$. aureus not only from human neutrophils, but also from non-professional phagocytic cells, such as epithelial cells $[133,135]$. Although PSMs do not lyse cells at submicromolar concentrations, they can trigger an inflammatory host response in neutrophils by interacting with the formyl peptide receptor 2 (FPR2) thereby contributing to the destructive inflammatory response characteristic of bacterial pneumonia $[83,133,134]$.

Several studies have reported a distinct role of PSMs in SAP. In a study using human lung epithelial cells, three PSMs demonstrated a dose-dependent cytotoxicity and interleukin (IL)-8 production [136]. Subsequent in vivo experiments using a murine $S$. aureus-influenza co-infection pneumonia model showed a significantly lower mortality rate in mice infected with a PSM-deficient mutant. Thus, PSMs contribute to a more severe outcome of pneumonia, highlighting their importance as a target for anti-infective therapy [136].

Hence, several approaches have been explored to target PSMs, in an attempt to counteract their pathologic function. Indirectly targeting PSMs by blocking the Agr system with an RNAIII-inhibiting peptide resulted in a decreased bacterial burden and a lower mortality rate in a mouse pneumonia model, along with reduced expression levels of $a g r, p s m \alpha$ and $p \sin \beta$ [83]. However, the protective effect of the RNAIII-inhibiting peptide was confined to neutrophils rather than macrophages. Indirect blocking of the transport system, the receptor binding or expression seems to hold more promise than neutralizing individual PSMs with $\mathrm{mAbs}$ because of the sequence diversity and functional redundancy of the seven PSMs [132].

\subsection{Cell Wall-Anchored Proteins}

Cell wall-anchored (CWA) proteins of S. aureus play a crucial role in its pathogenesis [137]. Several of those surface proteins have been associated with colonization of and adhesion to the respiratory epithelium in animal models of SAP [138,139].

\subsubsection{Fibronectin-Binding Protein A (FnBPA)}

Fibronectin-binding protein A (FnBPA) is one of two highly conserved fibronectin-binding proteins that are expressed by $S$. aureus and is most frequently encountered in strains isolated from patients suffering from bacteremia or infective endocarditis [98]. Moreover, it can promote S. aureus biofilm formation via its A domain [140]. Due to its ability to attach to the respiratory epithelium, and its association with biofilm formation, FnBPA has also been associated with HAP and VAP $[138,139]$.

In a recent study by Sharma-Kuinkel et al., patients with clinically cured SAP had higher IgM titers against FnBPA compared to patients with treatment failure, suggesting a protective role for anti-FnBPA Abs [103]. Based on this and other data, FnBPA emerged as an interesting virulence target in S. aureus research. Indeed, several Ab-based therapies against S. aureus biofilms have been attempted in preclinical studies, with FnBPA as a target molecule, and have been recently reviewed by Raafat et al. [141]. To date, there are no clinical trials involving FnBPA as a single protein vaccine [142]. However, FnBPA has been used in a novel bivalent fusion vaccine, SpA-D KKAA $-F_{n B P A} 37-507$ (SF), comprised of the D domain of staphylococcal protein A (SpA) and the A domain of FnBPA [98]. Active vaccination with SF in a murine pneumonia model reduced the bacterial burden in the lungs of 
infected animals, while passive immunization with rabbit polyclonal anti-SF IgG protected against S. aureus in a mouse bacteremia model.

\subsubsection{Staphylococcal Protein A (SpA)}

SpA, a multifunctional CWA protein, promotes immune evasion by disturbing the opsonophagocytic clearance of a pathogen [143]. Furthermore, it is the only B cell superantigen produced by S. aureus [47]. The role of SpA in the pathogenesis of SAP has been attributed to its ability to bind tumor necrosis factor receptor 1 (TNFR1) on lung epithelial cells, leading to the activation of intracellular signaling, the expression of chemokines (such as IL-8), and the recruitment of neutrophils [144]. This increases inflammation of the airway epithelium, and thus, contributes to tissue damage [137].

$\mathrm{SpA}$ has long been regarded as a promising vaccine target for $S$. aureus. A non-toxigenic SpA variant, termed $\mathrm{SpA} \mathrm{KKAA}_{\mathrm{A}}$, was developed, where each of the five Ig-binding domains of SpA was mutated to abolish its binding to the Fc portion of IgG and the $\mathrm{V}_{\mathrm{H}} 3^{+}$Fab fragments [145]. An anti$\mathrm{SpA}_{\mathrm{KKAA}} \mathrm{mAb}, 3 \mathrm{~F} 6$, was identified from mice immunized with $\mathrm{Sp} \mathrm{A}_{\mathrm{KKAA}}$, and found to neutralize the Fcy and $\mathrm{V}_{\mathrm{H}^{3}}{ }^{+}$Fab binding activity of SpA [146]. Passive immunization of neonatal mice with $3 F 6$ protected them against $S$. aureus sepsis, increased their protective immunity against subsequent staphylococcal infections [99], and prevented nasopharyngeal colonization [100]. A human anti-SpA $\mathrm{mAb}, 514 \mathrm{G} 3$, derived from an individual with naturally occurring anti-SpA Abs, effectively opsonized S. aureus and successfully saved mice from S. aureus-mediated bacteremia [101]. 514G3 entered a phase I-II clinical study in patients with $S$. aureus bacteremia and exhibited a favorable safety profile [98,102]. Further research into 514G3 in other $S$. aureus infection models was implied, but no concrete results have been published so far [101].

\subsubsection{S. aureus Surface Protein X (SasX)}

S. aureus surface protein $X($ SasX) is another CWA surface protein encoded predominantly in isolates found in Asia and Eastern Europe [84,137,147]. Its main function involves nasal colonization, but a role in biofilm formation and evasion of neutrophil killing has been reported [84,147-150]. The interest in Sas $X$ as a target was driven by the increased risk of colonized individuals to develop S. aureus infections [150], together with the higher incidence of sasX in HA-MRSA strains [148]. Vaccination with recombinant SasX led to an IgG1-dominated Ab response, as well as reduced acute lung injury and inflammation in a murine lung infection model. Interestingly, both active and passive immunizations reduced murine nasal S. aureus colonization [84].

\subsubsection{Staphylococcal Sortases (Srt)}

Sortases (Srt) represent a family of membrane-associated bacterial enzymes that belong to a family of transpeptidases that is responsible for anchoring secreted proteins into the peptidoglycan layer of Gram-positive bacteria [151]. Within S. aureus, there are two Srts, SrtA and SrtB. SrtA, the more studied one, anchors several S. aureus polypeptides, including Spa, FnBPA and FnBPB, ClfA and ClfB [117,152] to the cell wall via their recognition (LPXTG) motif [153]. SrtB, on the other hand, anchors the iron-regulated surface determinant protein $\mathrm{C}(\mathrm{IsdC})$ to the $S$. aureus surface via its recognition sequence NPQTN [152,153].

In SAP, only SrtB has been studied so far although with contradictory results. Bubeck et al. reported that in a mouse lung infection model, an $S$. aureus Newman $s r t B$ deletion mutation only resulted in a small reduction in mortality [85]. On the other hand, in an in vitro study by Wang et al., the SrtB inhibitor baicalin, which by itself does not kill S. aureus, reduced the adhesion of S. aureus to human lung epithelial cells A549, thus reducing the S. aureus-induced damage to these cells, as well as reducing macrophage J774 inflammatory activity [154]. Blocking the attachment of a pathogen to the host tissue may provide a potential alternative adjunctive therapy to conventional antibiotics in infection control [155]. Since many substrates of SrtA and SrtB are known virulence factors involved in 
the cell adhesion of $S$. aureus, pharmaceutical inhibitors of Srts are considered promising candidates in anti-infective therapy [154,156,157]. However, the use of neutralizing mAbs against Srts has not been investigated so far.

\section{Other Explored S. aureus Pneumonia-Related Targets}

\subsection{Panton-Valentine Leukocidin (PVL)}

Panton-Valentine leukocidin (PVL) is one of the best-described bi-component S. aureus toxins, since strains harboring the lukSF-PV gene have been linked to more severe and lethal infections [131]. Unlike the other leukocidin-encoding genes, lukSF-PV is not highly prevalent in the S. aureus population (5\% prevalence) [158], but is largely associated with CAP-causing MRSA strains [159]. Upon infection, it causes the release of a so-called "cytokine storm" (an over-activation of the immune system leading to high inflammatory cytokine titers) in lung epithelial cells, leading to increased lung inflammation and damage due to necrosis [41,160]. In contrast to other leukocidins, PVL does not possess hemolytic activity, due to an alternative tertiary conformation, which is unable to recognize the Duffy antigen receptor [161]. Nevertheless, isolates harboring the PVL-encoding genes, $l u k S-P V$ and $l u k F-P V$, have been linked to severe and fatal cases of necrotizing pneumonia (NP), making it an important target for drugs developed against SAP [162-166]. The role of PVL in the pathogenesis of NP and staphylococcal disease has been extensively reviewed in [167,168].

NP caused by PVL-harboring $S$. aureus can be treated with antibiotics (single or combination treatment), as proven by in vivo studies and several clinical case reports [169-171]. However, because of the high rates of antimicrobial resistance observed in various $S$. aureus lineages, other treatment options have been explored. For instance, treatment of polymorphonuclear leukocytes (PMNs) with commercial intravenous immunoglobulin (IVIG), often used in the treatment of severe S. aureus infections, was able to neutralize the cytotoxic effects of PVL. Further in vivo experiments using a rabbit SAP model showed a protective effect, both with IVIG alone and in combination with either vancomycin or linezolid [87]. IVIG treatment resulted in up to $100 \%$ reduction in mortality when treating CA-MRSA-induced pneumonia, whereas only $50 \%$ mortality reduction was observed when a HA-MRSA (USA100/NRS382) strain was used [87]. Attenuated PVL components (LukS-PV T28F/K97A/S209A and LukF-PV $\mathrm{K}_{102 \mathrm{~A}}$ ) provided protection in a mouse sepsis model, and lead to partial protection in a NP rabbit model $[86,88]$. A combination therapy based on these components is described under "7. Multicomponent vaccines". Other mAbs targeting LukS-PV were developed for diagnostic purposes but were not tested for neutralizing capabilities [89]. Finally, since PVL induces a cytokine storm during pneumonia, anti-inflammatory drugs have also been under investigation to reduce its pathologic effects. Treatment with Anakinra (Swedish Orphan Biovitrum AB, Stockholm, Sweden), human IL-1 receptor antagonist protein used in rheumatoid arthritis [172], resulted in decreased cytokine production in a PVL-induced NP rabbit model. Unfortunately, Anakinra therapy did not show a comparable effect when probed in SAP [173].

\subsection{S. aureus Extracellular Vesicles (SEVS)}

S. aureus extracellular vesicles (SEVs) are lipid bi-layered nanoparticles (20-200 $\mathrm{nm}$ in size) containing cytosolic proteins, membrane proteins, peptidoglycan, lipoteichoic acid and many pathogenic molecules, such as enterotoxin (SEQ), IgG-binding protein (Sbi) and hemolysins [90,91,174]. Although the mechanism remains unclear, SEV-associated proteins can influence bacteria-host interactions during systemic infections, and induce a host immune response, albeit in a different way than secreted proteins. Vaccination with SEVs induced an adaptive immune response, as judged by serum SEV-reactive IgG and IgM levels and T cell responses [90-93]. Moreover, administration of SEVs increased the resistance of $S$. aureus to killing by whole blood or purified human neutrophils ex vivo and increased in vivo survival [90]. The effects of SEV immunization on SAP and mortality were studied, where immunized mice were protected against $S$. aureus-induced infection [92]. 
The structure of SEVs could provide a powerful and innovative strategy as drug delivery vehicle as well as vaccination agent with many advantages, including their nano-scale size, favorable toxicity profile, intracellular location, activation of both innate and adaptive immune systems and non-requirement of adjuvants [91-93].

\subsection{Lipoteichoic Acid (LTA)}

Lipoteichoic acid (LTA) is a major CWA of most Gram-positive bacteria. Structurally, it is a polymer of teichoic acids (TAs), which in turn consist of polyanionic repeating units bound together with phosphodiester bonds, that is linked to the outer leaflet of the cytoplasmic membrane via a glycolipid anchor [175]. LTA is an example of pathogen-associated molecular patterns [PAMPs], which are highly conserved motifs recognized by pattern-recognition receptors displayed by phagocytic cells involved in host defense, the Toll-like receptors (TLRs). Their recognition leads to the activation of intracellular signaling cascades, ultimately resulting in a proinflammatory response and activation of the innate immune system [176,177].

Recognition of PAMPs by TLRs is considered to be important for an appropriate immune response against pathogens that enter the lower airways. In vitro, LTA has potent proinflammatory and pro-apoptotic effects on human alveolar macrophages, which are the major effector cells in host defense against respiratory tract infections [94]. Moreover, LTA, acting via TLR2, elicits neutrophil recruitment into the pulmonary compartment both in mice as well as humans, ultimately resulting in pulmonary inflammation $[95,96]$. It also activates bronchoalveolar coagulation with concurrent inhibition of anticoagulant and fibrinolytic mechanisms, and thus affects hemostasis in humans [97].

Despite the fact that LTA is a crucial component of $S$. aureus, by itself, it is deemed unsuitable as a vaccine candidate, since it is a thymus-independent antigen, which has weak immunogenicity, and which cannot sufficiently induce immune memory. This limitation might be overcome by alternatives, such as the conjugation of LTA as a polysaccharide antigen to a carrier protein, an approach that has been successfully implemented in a number of carbohydrate conjugate vaccines, such as the pneumococcal 13-valent (Prevenar $13^{\circledR}$, Pfizer, New York City, NY, United States) and the Haemophilus influenza typa b (HiB) conjugate vaccines [178]. Another alternative was reported by Yi et al., where they identified a tetra-branched multiple antigenic peptide, named MAP2-3, that can mimic the epitope of LTA [179]. Immunization with MAP2-3 as a surrogate of LTA elicited humoral immune response (including high levels of functional LTA-specific IgG Abs), and protected mice from S. aureus systemic infection. Moreover, passive immunization with polyclonal anti-MAP2-3 sera mitigated acute lung injury in mice with pneumonia, and also proved useful in bacteremia and skin infection models [179].

\section{Potential Unexplored Targets in S. aureus Pneumonia}

\subsection{Leukocidin $A B(L u k A B)$}

Leukocidin $\mathrm{AB}$ (LukAB; sometimes referred to as LukGH) was recently discovered, when isogenic mutants of $S$. aureus Newman, with disrupted AT-, Hlg- or leukocidin ED (LukED)-encoding genes, showed high cytotoxicity against human immune cells. Exoproteome analysis revealed LukAB as the main contributor to human phagocyte killing [180]. Besides the active killing of innate immune cells, LukAB also disrupts the adaptive immune response by directly killing dendritic cells, and by blocking dendritic cell-mediated activation and proliferation of $\mathrm{CD}^{+} \mathrm{T}$ cells [181]. Remarkably, it was found that LukAB not only enhances the formation of neutrophil extracellular traps (NETs), that immobilize pathogens and attract phagocytes, but also leads to nonspecific host tissue damage [182].

Despite the cytopathogenesis of LukAB, and the fact that several neutralizing $m A b s$ have been developed, it has not yet been investigated in SAP models. Three LukAB-specific human mAbs, which were generated from human B cells, neutralized LukAB cytotoxicity, and improved bacterial clearance in a murine $S$. aureus sepsis model [105]. Moreover, neutralizing Abs were recently generated from two $S$. aureus strains with mutated $l u k A B$ genes $\left(L^{2 u k A_{D 39 A}}\right.$ and $L u k B_{R 23 E}$ ), which were able to 
block the CD11b cellular target, and prevent LukAB-dependent cell lysis in a human monocytic cell line [106]. These components were also tested as part of a multivalent toxoid vaccine, described under "7. Multicomponent vaccines". Similar to what has been observed for PVL, commercial IVIG has been shown to contain neutralizing anti-LukAB [107].

\subsection{Leukocidin ED (LukED)}

Leukocidin ED (LukED) is another bi-component toxin, where the tertiary protein configuration of the core domains shows high structural similarity to those of other leukocidins [183]. The genes encoding the toxin subunits, lukED, are highly conserved in MRSA clones isolated across the world, with up to $85 \%$ carriage rates [131], especially among epidemic strains [184]. In addition to innate immune cells, LukED also kills cells that carry the CCR5 receptor found on myeloid and effector memory T lymphocytes; hence, CCR5-deficient mice are protected from LukED-mediated killing [108,185]. Therefore, analogous to LukAB, LukED is capable of disrupting the host's innate as well as adaptive immune systems.

Given that LukED uses CCR5 as receptor, a potentially interesting treatment option was found in maraviroc (Pfizer, New York City, NY, United States), a small-molecule entry inhibitor of CCR5, used in the treatment of human immunodeficiency virus (HIV) infection. HIV and LukED share the CCR5 receptor as a cellular target, but bind to different sequence determinants $[108,186]$. Nevertheless, maraviroc was shown to render murine macrophages partially resistant to LukED-mediated killing [186], as well as to inhibit LukED functionality in human HEK293T and SupT1 cell lines [108].

\subsection{Ferric Uptake Regulator (Fur)}

Members of the ferric uptake regulator (Fur) family of transcription regulators are found in most Gram-positive and Gram-negative bacteria, and are involved in the regulation of iron and zinc metabolism [187]. Fur-mediated regulation of iron metabolism has been described in detail in a series of recent reviews $[187,188]$. While investigating the role of Fur in a murine SAP model, Torres et al. demonstrated that $S$. aureus lacking Fur was more susceptible to neutrophil-mediated killing. Furthermore, the bacterial load in animals infected with the wild type S. aureus was approximately 1.5-log greater than in those animals infected with the fur deletion mutant [104]. To our knowledge, Fur has not been investigated as a target for active or passive immunization, but since it is involved in the expression of many pneumonia-associated S. aureus virulence factors, such as Hla, HlgA, LukED, and LukSF, it might be a promising candidate for future vaccine studies.

\section{Multicomponent Vaccines}

The focus in the last couple of years has been increasingly shifting towards targeting multiple $S$. aureus virulence factors simultaneously. An increasing number of studies are providing evidence that vaccines consisting of two or more components have a higher protective potential in mouse models than those involving either of the individual proteins [98,189]. For instance, active immunization with the SF fusion vaccine (see "Section 4.3.1. Fibronectin-binding protein A (FnBPA)") induced a strong Ab response, together with a Th1/Th17-polarized cellular response, and was thus more protective against different $S$. aureus strains in three different mouse models of infection (sepsis, skin infection and SAP), compared to either of the single components, highlighting the greater potential of multicomponent vaccine approaches [98]. Therefore, despite a seemingly long list of potential vaccine targets currently under consideration for both preclinical and clinical trials, most researchers support the notion that multicomponent vaccines might be the future of vaccine research [190-192].

An overview of the current $S$. aureus multicomponent vaccines, and their corresponding targets, is given in Figure 1. We will highlight some in the following paragraphs. 


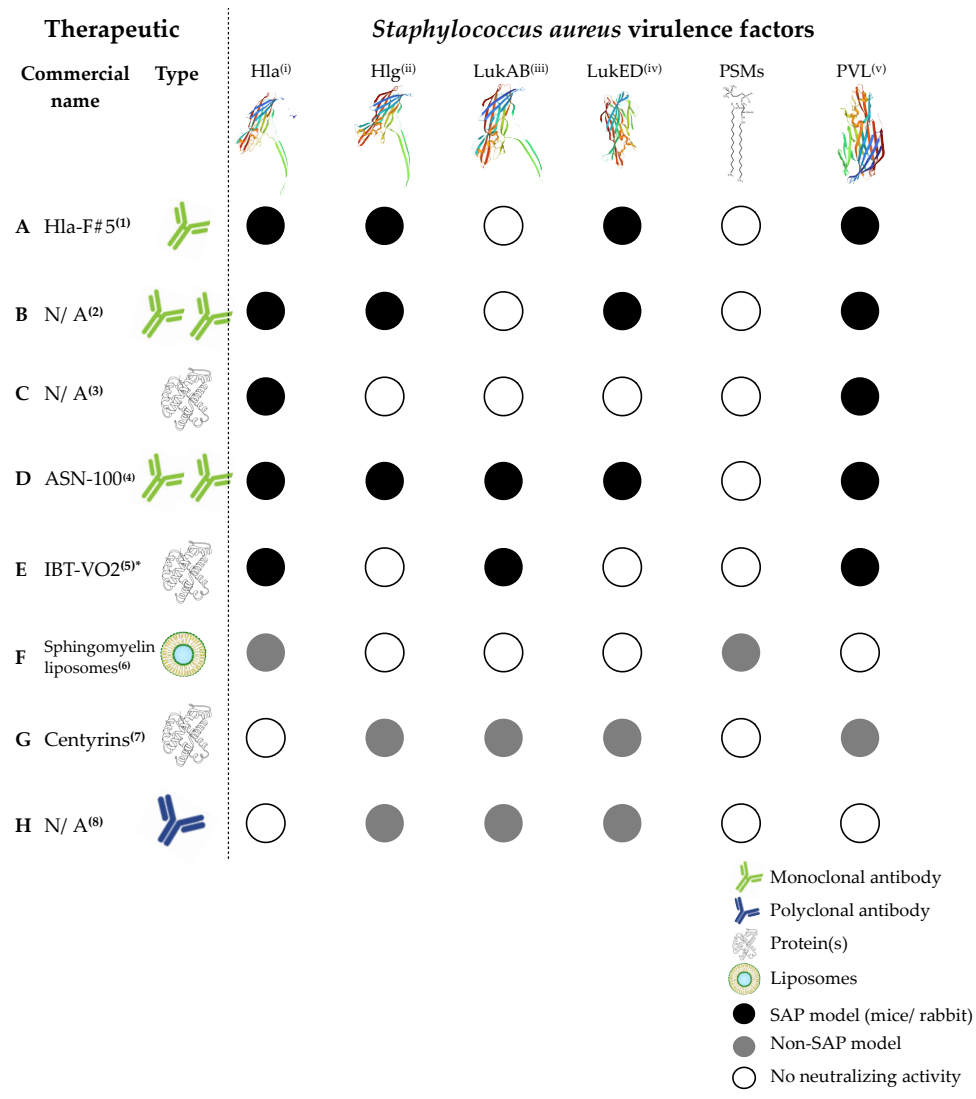

Figure 1. Therapeutics targeting multiple $S$. aureus virulence factors. The most commonly investigated virulence factors of S. aureus are Hla: Alpha-toxin; Hlg: Gamma-toxin; LukAB: Leukocidin AB; LukED: Leukocidin ED; PSMs: Phenol-soluble modulins and PVL: Panton Valentine leukocidin. Hla and PVL are often included in multivalent $S$. aureus vaccines, while PSMs are not. SAP: S. aureus pneumonia; N/A: not available. *: also neutralizes enterotoxins A and B and toxic shock syndrome toxin 1. (1): [193,194]; (2): [195]; (3): [86]; (4): [74,196]; (5): [197,198]; (6): [199]; (7): [200]; (8): [201]. (i): [202]; (ii): [203]; (iii): [204]; (iv): [183]; (v): [205].

\subsection{Therapeutics Neutralizing Multiple Leukocidins}

A promising $\mathrm{mAb}$ tested in the context of pneumonia was Hla-F\#5 (Figure 1A), which cross-reacts with Hla, gamma-hemolysin (HlgAB and HlgCB), LukED and PVL [193]. A study showed that passive immunization of mice suffering from SAP with this monoclonal Ab drastically increased their survival rate. Similar results were later obtained by Diep et al. in a rabbit pneumonia model [194].

More promising results by the Diep group came from two studies conducted in a NP rabbit model. The first study showed that passive immunization using a combination of an Hla-specific $\mathrm{mAb}$ (suvratoxumab) with a cross-neutralizing leukocidin mAb (SAN177 or SAN481) reduced mortality to $7 \%$ and $0 \%$, respectively (Figure 1B) [195]. The second study showed similar results when attenuated

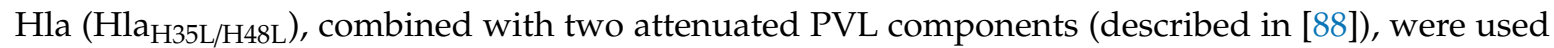
for active immunization [86], where $100 \%$ protection from lethality was observed in immunized rabbits (Figure 1C). Besides Hla-F\#5, the Nagy research group also developed a second combination of two mAbs, termed ASN100 (Figure 1D). ASN100 consists of ASN-1, which neutralizes Hla, PVL, LukED, and Hlg, as well as ASN-2, which is specific to LukAB. Administration of this Ab-combination protected human PMNs and white blood cells against lysis [196]. ASN100 was then further tested in rabbit pneumonia models, where passive immunization increased survival and protection against MRSA- and MSSA-induced pneumonia [74]. This led to a phase II interventional trial, where heavily S. aureus-colonized, mechanically ventilated patients were treated with ASN-100 (Clinical Trials Identifier: NCT02940626). However, there was no significant reduction in the incidence of SAP on day 22 (Table 3). 
Table 3. Clinical trials on S. aureus pneumonia.

\begin{tabular}{|c|c|c|c|c|c|c|c|c|c|}
\hline Antigen(s) & Year & Type of Study ${ }^{a}$ & Study Title & $\begin{array}{c}\text { No. of } \\
\text { Subjects }\end{array}$ & Aim & $\begin{array}{l}\text { Clinical Trials } \\
\text { Identifier }\end{array}$ & Countries $^{b}$ & Status of Trial & Outcome \\
\hline $\mathrm{SpA}$ & 2015 & I, R & $\begin{array}{l}\text { A I-II study of the safety and } \\
\text { efficacy of a true human } \\
\text { antibody, 514G3, in subjects } \\
\text { sospitalized with bacteremia } \\
\text { due to } \text { S. aureus }\end{array}$ & 52 & $\begin{array}{l}\text { Evaluating the safety } \\
\text { of } 514 \mathrm{G} 3 \text { in patients } \\
\text { with } S \text {. aureus } \\
\text { bacteremia }\end{array}$ & NCT02357966 & US & completed & Results ${ }^{c}$ \\
\hline PVL & 2016 & $\mathrm{O}, \mathrm{NR}$ & $\begin{array}{l}\text { Panton-Valentine leucocidin: } \\
\text { independent severity factor of } \\
\text { S. aureus pneumonias }\end{array}$ & 234 & $\begin{array}{l}\text { Assessing patient } \\
\text { survival according } \\
\text { to the PVL } \\
\text { character of isolated } \\
\text { S. aureus strains }\end{array}$ & NCT02798497 & FR & completed & $\begin{array}{l}\text { No published } \\
\text { results }\end{array}$ \\
\hline PVL & 2017 & $\mathrm{O}, \mathrm{Re}$ & $\begin{array}{c}\text { Epidemiology of } \\
\text { post-influenza bacterial } \\
\text { pneumonia due to a } \\
\text { Panton-Valentine leukocidin } \\
\text { positive } \text { S. aureus } \\
\text { (FLUVALENTINE) }\end{array}$ & 35 & $\begin{array}{l}\text { Evaluating the } \\
\text { mortality of ICU } \\
\text { patients with } \\
\text { post-influenza } \\
\text { bacterial pneumonia } \\
\text { due to a PVL+ } \\
\text { S. aureus }\end{array}$ & NCT03367624 & FR & unknown & $\begin{array}{l}\text { No published } \\
\text { results }\end{array}$ \\
\hline Hla & 2019 & I, R & $\begin{array}{l}\text { A phase II randomized, } \\
\text { double-blind, } \\
\text { placebo-controlled, single-dose, } \\
\text { dose-ranging study of the } \\
\text { efficacy and safety of } \\
\text { MEDI4893, a human } \\
\text { monoclonal antibody against } S \text {. } \\
\text { aureus alpha Toxin in } \\
\text { mechanically ventilated adult } \\
\text { subjects (SAATELLITE) }\end{array}$ & 213 & $\begin{array}{l}\text { Studying the efficacy } \\
\text { and safety of } \\
\text { MEDI4893 } \\
\text { (suvratoxumab) }\end{array}$ & NCT02296320 & $\begin{array}{l}\text { BE, CH, CZ, } \\
\text { ES, FR, DE, } \\
\text { GR, HU, PT, } \\
\text { US }\end{array}$ & completed & $\begin{array}{l}\text { Preliminary } \\
\text { results d } \\
\text { Results } \mathrm{e}\end{array}$ \\
\hline
\end{tabular}


Table 3. Cont

\begin{tabular}{|c|c|c|c|c|c|c|c|c|c|}
\hline Antigen(s) & Year & Type of Study ${ }^{a}$ & Study Title & $\begin{array}{c}\text { No. of } \\
\text { Subjects }\end{array}$ & Aim & $\begin{array}{l}\text { Clinical Trials } \\
\text { Identifier }\end{array}$ & Countries ${ }^{b}$ & Status of Trial & Outcome \\
\hline $\begin{array}{c}\text { Hla, } \\
\text { LukSF-PV, } \\
\text { LukED, Hlg, } \\
\text { LukGH }\end{array}$ & 2019 & $\mathrm{I}, \mathrm{R}$ & $\begin{array}{l}\text { A phase II, randomized, } \\
\text { double-Blind, } \\
\text { placebo-controlled study to } \\
\text { determine the safety and } \\
\text { efficacy of a single dose of } \\
\text { ASN100 for the prevention of } S \text {. } \\
\text { aureus pneumonia in heavily } \\
\text { colonized, mechanically } \\
\text { ventilated subjects }\end{array}$ & 155 & $\begin{array}{l}\text { Assessing prevention } \\
\text { of SAP in } \\
\text { mechanically } \\
\text { ventilated, heavily S. } \\
\text { aureus-colonized } \\
\text { subjects }\end{array}$ & NCT02940626 & $\begin{array}{l}\text { AT, CZ, ES, } \\
\text { FR, GE, HU, } \\
\text { IL, IN, PL, } \\
\text { PT, RO, RS, } \\
\text { RU, UA, US, } \\
\text { ZA }\end{array}$ & completed & $\begin{array}{l}\text { No published } \\
\text { results }\end{array}$ \\
\hline Hla & 2020 & $\mathrm{I}, \mathrm{R}$ & $\begin{array}{l}\text { A randomized, double-blind, } \\
\text { placebo-controlled, single } \\
\text { ascending dose study to assess } \\
\text { the safety, pharmacokinetics, } \\
\text { efficacy and } \\
\text { pharmacodynamics of } \\
\text { KBSA301 in severe pneumonia } \\
\text { (S. aureus) }\end{array}$ & 48 & $\begin{array}{l}\text { Evaluating the safety, } \\
\text { pharmacokinetics and } \\
\text { efficacy of KBSA301 } \\
\text { in severe SAP }\end{array}$ & NCT01589185 & $\begin{array}{l}\text { BE, ES, FR, } \\
\text { US }\end{array}$ & completed & $\begin{array}{l}\text { Preliminary } \\
\text { results } \mathrm{f}\end{array}$ \\
\hline
\end{tabular}


A final, interesting, multivalent vaccine currently under development is IBT-VO2 (Figure 1E). This heptavalent vaccine contains rationally designed Hla, PVL LukS, LukF, LukAB, enterotoxins A and B and toxic shock syndrome toxin 1 toxoids [197]. Due to structural similarities, the multi-subunit vaccine elicits an antibody response that is cross-reactive with 12-15 S. aureus toxins and protects from S. aureus disease in multiple mouse and rabbit infection models [198]. Following the current pre-clinical phase, IBT-VO2 will enter a phase I clinical trial and hence recently received extra financial support to advance its development [206].

\subsection{Multitarget Therapeutics Involving PSMs}

In an interesting approach, Wolfmeier et al. used sphingomyelin liposomes (Figure 1F), either with or without cholesterol, to neutralize secreted PSMs, together with other virulence factors, both in vitro (human S. aureus blood and epithelial cell infections) and in a murine dermonecrosis model [199]. Sphingomyelin liposomes prevented cell lysis by PSMs, especially PSM $\alpha 3$, in all cell types, whereas sphingomyelin liposomes containing cholesterol specifically sequestered Hla.

Both liposome types reduced the extent of murine dermonecrosis [199]. It is noteworthy to mention that a mixture of both liposome types has recently been tested in a phase I clinical study against severe pneumococcal pneumonia (Clinical Trials Identifier: NCT02583373), but its usefulness in SAP is yet to be determined. Furthermore, it seems advisable to target PSMs and Hla simultaneously, since it was shown that PSMs regulate the production of Hla both in vitro and in vivo [207]. A mutant strain deficient for PSM $\alpha, \operatorname{PSM} \beta$, and delta-toxin produced relatively lower amounts of Hla and exhibited reduced virulence in murine skin infection and pneumonia models [191].

\section{Current Issues Hampering S. aureus Vaccine Research}

Despite much research focused on targeting S. aureus virulence factors, no suitable vaccine is yet available. mAbs neutralizing single factors have been developed successfully, but many of the conducted in vitro studies did not reach clinical potential (Table 3). This is due to the redundancy of most of the above-mentioned virulence factors [201], as well as their complex regulatory mechanisms [208]. Targeting the regulatory factors like Fur and Agr might indeed be taken into consideration, as has already been shown in the case of PSMs [83].

However, one needs to keep in mind that Abs solely targeting S. aureus virulence factors might have a lower efficacy against HA-MRSA, despite the use of multicomponent vaccines. As mentioned, above HA-MRSA lineages harbor less chromosomal virulence factors and express them in lower quantities than CA-MRSA. Therefore, inhibiting those factors in HA-MRSA might prove to be ineffective. Also, there have been indications that an antibody-based therapy is more efficient in SAP patients with low S. aureus colonization levels [209], further complicating the use of Abs to treat SAP patients. However, prophylactic use of Abs could still be considered in said cases.

Another obstacle facing $S$. aureus vaccine research lies in the fact that many of the virulence-targeting therapeutics have been initially tested in murine SAP models. This is however a huge limitation, since some toxic virulence factors, such as Hla, leukocidins, and PVL, exhibit a high level of host tropism. Whereas PVL actively kills human and rabbit PMNs, murine PMNs are immune to its cytotoxicity [194]. On the other hand, LukAB shows a reduced activity towards rabbit and murine PMNs [210], which exhibit a lower affinity variant of the CD11b target [211]. The absence of appropriate small animal models could be overcome by the use of genetically modified (i.e., "humanized") mice. Indeed, mice with a human hematopoietic system showed similar vulnerability to PVL as observed in studies performed in rabbits or human cell lines [212]. Alternatively, mouse-adapted S. aureus strains can be used to optimize murine in vivo models [213,214]. However, this might still prove to be difficult to transfer to human-infecting strains. Instead of adapting the model, a modification of the toxin might achieve a similar goal. For instance, a recombinant LukAB protein showed equal cytotoxicity towards rabbit as well as human PMNs [215]. 


\section{Alternative Therapeutic Strategies}

\subsection{Bacteriophages}

The current worldwide epidemic of increasing antimicrobial resistance is accompanied by a greater understanding of the damage broad spectrum antibiotics have on the healthy microbiome. Hence, alternative approaches-other than antimicrobials-have lately garnered the attention of researchers, in an attempt to treat multidrug resistant pathogens. One such alternative, which has also been explored in the context of SAP, is phage therapy, where bacteriophages are used to selectively target the infecting pathogen. In one study involving mice with lung-derived septicemia, treatment with S. aureus $\varphi S 13^{\prime}$ increased murine survival from $10 \%$ to $67 \%$ [216]. Another randomized, blinded, controlled in vivo experimental study compared the efficacy of phage therapy versus teicoplanin treatment in rats with MRSA-induced VAP [217]. The administration of a four phage cocktail, increased rat survival to $58 \%$, comparable to teicoplanin treatment (50\%). In another study, conducted by the same research group and published in 2020, rats with MRSA-induced VAP were treated prophylactically with nebulized bacteriophages, resulting in increased survival (70\% versus $0 \%$ in the control group) as well as a reduced bacterial burden [218].

Another promising treatment option involves the bacteriophage cocktail AB-SA01 that contains three myoviruses related to Staphylococcus $\varphi \mathrm{K}$ [219]. The product killed $94.5 \%$ of the 205 clinical S. aureus isolates tested in vitro, which included both MRSA as well as vancomycin-intermediate S. aureus (VISA) [219]. Moreover, in a BALB/c mouse acute pneumonia model, it was shown that bacterial clearance in the lungs of AB-SA01-treated mice was comparable to that in mice treated with vancomycin. An additional benefit of AB-SA01 over antibiotics is that the frequency of spontaneous resistance was found to be low. In clinical testing, AB-SA01 was deemed safe and well-tolerated when administered intranasally in patients suffering from chronic rhinosinusitis, and thus became the first clinical trial with intravenous phage therapy to be approved in the USA [220]. In an ensuing single-arm, non-comparative clinical trial, intravenous administration of AB-SA01 in 13 patients with severe $S$. aureus infections, including endocarditis and septic shock, did not show any adverse reactions. More interestingly, eight patients survived and showed clinical improvement after 14 days of treatment [221]. Further controlled clinical trials are to be expected.

Besides using the phage itself for treatment, other studies explored a possible use of phage-derived lysines. A 2015 study investigating the efficacy of LysGH15 showed that treatment with the lysine achieved $80 \%$ survival in mice with SAP. The survival rate further increased to $100 \%$ when LysGH15 was combined with apigenin, a naturally occurring flavonoid [222]. In a second study, conducted in 2018, phage-derived endolysin SAL200 was tested in murine SAP, and achieved higher survival, lower bacterial burden, and improved lung histopathology compared to the control group [223].

Benefits of phage therapy are the little to no adverse host reactions, generally low frequency of spontaneous resistance against the bacteriophage, and their ability to target and kill multidrug resistant clones [219]. However, phage therapy also has its limitations, including strain specificity and the potential for immunogenicity preventing repeat dosing [224].

\subsection{Outer Membrane Vesicles (OMVs)}

Another interesting approach exploits bacterial outer membrane vesicles (OMVs) as a vehicle for delivering foreign antigens into the host, with the aim of eliciting protective immune responses. For instance, Irene et al. expressed five highly conserved $S$. aureus vaccine candidates $\left(\mathrm{Hla}_{\mathrm{H} 35 \mathrm{~L}}\right.$, $\mathrm{SpA}_{\mathrm{KKAA}}$, FhuD2, Csa1A, and LukE) in Escherichia coli as fusions to a lipoprotein leader sequence. The lipoproteins were compartmentalized in OMVs and elicited high antigen-specific $\mathrm{Ab}$ titers in immunized mice. Moreover, the penta-valent OMV-based S. aureus vaccine protected mice from challenge with the S. aureus Newman strain in a sepsis model [225]. This suggests that those engineered OMVs could represent a valid alternative for the development of an efficacious $S$. aureus vaccine. 


\section{Concluding Remarks}

In conclusion, much effort has been invested in exploring $S$. aureus virulence factors, thus improving our understanding of their mode of action and their role in SAP pathogenesis (Table 2). Classical immunization strategies involving the use of Abs have led to the development of several promising therapeutics. However, many hurdles still remain in the path of an effective SAP vaccine given the intricate genetic background of $S$. aureus (Table 4). Finally, apart from classical methods of active and passive immunization, alternative approaches should be considered (Table 4). SEVs and OMVs could provide innovative ways of drug delivery, while phage therapy provides an interesting lead showing some success in different clinical settings. A systems biology approach combining data generated from genomic, proteomic, and metabolomic studies is necessary to further our knowledge on bacteria-host interactions. Moreover, much attention has recently been dedicated to the respiratory microbiome and its effect on pneumonia pathogenesis. These studies debate Koch's postulates and raise the question that if one pathogen is suppressed, another might prevail. More research will hence be required in these directions in order to develop a safe and effective SAP therapeutic.

Table 4. Current issues hampering $S$. aureus vaccine research and alternative therapeutic strategies.

\begin{tabular}{|c|c|c|}
\hline (A) Issues Hampering S. aureus Vaccine Research & Potential Solution & References \\
\hline $\begin{array}{c}\text { Redundancy of S. aureus virulence factors } \\
\text { Genetic variations among S. aureus isolates/lineages } \\
\text { Complex regulatory mechanisms }\end{array}$ & Target regulatory factors & {$[83,201,208]$} \\
\hline Lower presence and expression of virulence factors in HA-MRSA & & {$[34,35]$} \\
\hline $\begin{array}{l}\text { Antibody-based therapy less effective in highly } \\
\text { colonized SAP patients }\end{array}$ & $\begin{array}{l}\text { Prophylactic antibody use } \\
\text { to be explored }\end{array}$ & [209] \\
\hline $\begin{array}{c}\text { High tropism of } S \text {. aureus virulence factors } \\
\text { Inferior transferability of conventional mouse models } \\
\text { into clinical research }\end{array}$ & $\begin{array}{l}\text { Humanized mice } \\
\text { Mouse-adapted S. aureus strains } \\
\text { Recombinant toxins }\end{array}$ & $\begin{array}{c}{[194,210-215]} \\
10.3390 / \text { ijms21197061 }\end{array}$ \\
\hline (B) Alternative Therapeutic Strategies & Explored in SAP & References \\
\hline Bacteriophages & Yes & [216-224] \\
\hline Outer membrane vesicles & No & {$[225]$} \\
\hline Nanoparticles (nasal vaccination) & No & 10.1016/j.addr.2008.09.005 \\
\hline Nanoparticles (treatment of pulmonary diseases) & Yes & $\begin{array}{c}\text { 10.1002/wnan. } 1401 \\
10.1038 / \mathrm{s} 41551-017-0187-5\end{array}$ \\
\hline Antimicrobial peptides (antibiotic alternative) & No & 10.1093/jac/dkw381 \\
\hline
\end{tabular}

HA-MRSA: Hospital-associated methicillin-resistant S. aureus; SAP: S. aureus pneumonia.

Author Contributions: Conceptualization, S.M.-K.; data collection and writing: J.V., D.R., K.S., L.T. and N.N.; writing—compilation original draft, J.V.; writing—review and editing, J.V., D.R., K.S., L.T., N.N., B.S., W.J.v.W. and S.M.-K.; supervision, S.M.-K.; All authors have read and agreed to the published version of the manuscript.

Funding: J.V.: K.S., L.T., and N.N. were supported by the Innovative Medicines Initiative project COMBACTE (Combatting Bacterial Resistance in Europe). This research project receives support from the Innovative Medicines Initiative Joint Undertaking under grant agreement $n^{\circ} 115523$ resources of which are composed of financial contribution from the European Union Seventh Framework Programme (FP7/2007-2013) and EFPIA companies in kind contribution. J.V. was also supported by IWT-SBO project \#140746.

Acknowledgments: We would like to thank Barbara M. Bröker and Uwe Völker (University Medicine Greifswald) for their valuable input in the drafting of the manuscript.

Conflicts of Interest: J.V., D.R., K.S., L.T., N.N., W.W. and S.M.-K. do not have a commercial or other association that poses a conflict of interest. B.S. is employed by AstraZeneca, manufacturer of monoclonal antibodies. The funders had no role in the design of the study; in the collection, analyses, or interpretation of data; in the writing of the manuscript, or in the decision to publish the results.

\section{References}

1. Dadonaite, B. Pneumonia. Available online: https://ourworldindata.org/pneumonia (accessed on 3 September 2020).

2. World Health Organization. Pneumonia. Available online: https://www.who.int/news-room/fact-sheets/ detail/pneumonia (accessed on 3 September 2020). 
3. United Nations Children's Fund. Pneumonia. Available online: https://data.unicef.org/topic/child-health/ pneumonia/ (accessed on 3 September 2020).

4. MacKenzie, G. The definition and classification of pneumonia. Pneumonia 2016, 8, 1-5. [CrossRef] [PubMed]

5. Centers for Disease Control and Prevention. Causes of Pneumonia. Available online: https://www.cdc.gov/ pneumonia/causes.html (accessed on 30 June 2020).

6. Laterre, P.-F.; Garber, G.; Levy, H.; Wunderink, R.; Kinasewitz, G.T.; Sollet, J.-P.; Maki, D.G.; Bates, B.; Yan, S.C.B.; Dhainaut, J.-F. Severe community-acquired pneumonia as a cause of severe sepsis: Data from the PROWESS study. Crit. Care Med. 2005, 33, 952-961. [CrossRef] [PubMed]

7. Dalhoff, K.; Abele-Horn, M.; Andreas, S.; Deja, M.; Ewig, S.; Gastmeier, P.; Gatermann, S.; Gerlach, H.; Grabein, B.; Heußel, C.P.; et al. Epidemiologie, Diagnostik und Therapie erwachsener Patienten mit nosokomialer Pneumonie-Update 2017-S3 Guideline of the German Society for Anaesthesiology and Intensive Care Medicine, the German Society for Infectious Diseases, the German Society for Hygiene and Microbiology, the German Respiratory Society and the Paul-Ehrlich-Society for Chemotherapy, the German Radiological Society and the Society for Virology. Pneumologie 2018, 72, 15-63. [CrossRef] [PubMed]

8. Kalil, A.C.; Metersky, M.L.; Klompas, M.; Muscedere, J.; Sweeney, D.A.; Palmer, L.B.; Napolitano, L.M.; O'Grady, N.P.; Bartlett, J.G.; Carratalà, J.; et al. Management of Adults with Hospital-acquired and Ventilator-associated Pneumonia: 2016 Clinical Practice Guidelines by the Infectious Diseases Society of America and the American Thoracic Society. Clin. Infect. Dis. 2016, 63, e61-e111. [CrossRef] [PubMed]

9. Uhlemann, A.-C.; Otto, M.; Lowy, F.D.; DeLeo, F.R. Evolution of community- and healthcare-associated methicillin-resistant Staphylococcus aureus. Infect. Genet. Evol. J. Mol. Epidemiol. Evol. Genet. Infect. Dis. 2014, 21, 563-574. [CrossRef] [PubMed]

10. Kollef, M.H.; Micek, S.T. Staphylococcus aureus pneumonia: A "superbug" infection in community and hospital settings. Chest 2005, 128, 1093-1097. [CrossRef]

11. Lanks, C.W.; Musani, A.I.; Hsia, D.W. Community-acquired Pneumonia and Hospital-acquired Pneumonia. Med. Clin. N. Am. 2019, 103, 487-501. [CrossRef]

12. Micek, S.T.; Kollef, K.E.; Reichley, R.M.; Roubinian, N.; Kollef, M.H. Health Care-Associated Pneumonia and Community-Acquired Pneumonia: A Single-Center Experience. Antimicrob. Agents Chemother. 2007, 51, 3568-3573. [CrossRef]

13. Ewig, S.; Höffken, G.; Kern, W.V.; Rohde, G.; Flick, H.; Krause, R.; Ott, S.R.; Bauer, T.; Dalhoff, K.; Gatermann, S.; et al. Behandlung von erwachsenen Patienten mit ambulant erworbener Pneumonie und Prävention-Update 2016. Pneumologie 2016, 70, 151-200. [CrossRef]

14. Rotstein, C.; Evans, G.; Born, A.; Grossman, R.; Light, R.B.; Magder, S.; McTaggart, B.; Weiss, K.; Zhanel, G.G. Clinical Practice Guidelines for Hospital-Acquired Pneumonia and Ventilator-Associated Pneumonia in Adults. Can. J. Infect. Dis. Med. Microbiol. 2008, 19, 19-53. [CrossRef]

15. Qi, F.; Zhang, G.-X.; She, D.-Y.; Liang, Z.-X.; Wang, R.-T.; Yang, Z.; Chen, L.-A.; Cui, J.-C. Healthcare-associated Pneumonia. Chin. Med. J. 2015, 128, 2707-2713. [CrossRef] [PubMed]

16. Torres, A.; Lee, N.; Cilloniz, C.; Vila, J.; Van Der Eerden, M. Laboratory diagnosis of pneumonia in the molecular age. Eur. Respir. J. 2016, 48, 1764-1778. [CrossRef] [PubMed]

17. Jacobs, D.M.; Shaver, A. Prevalence of and outcomes from Staphylococcus aureus pneumonia among hospitalized patients in the United States, 2009-2012. Am. J. Infect. Control. 2017, 45, 404-409. [CrossRef] [PubMed]

18. Paling, F.P.; Hazard, D.; Bonten, M.J.M.; Goossens, H.; Jafri, H.S.; Malhotra-Kumar, S.; Sifakis, F.; Weber, S.; Kluytmans, J.A.J.W.; for the ASPIRE-ICU Study Team. Association of Staphylococcus aureus Colonization and Pneumonia in the Intensive Care Unit. JAMA Netw. Open 2020, 3, e2012741. [CrossRef]

19. Watanakunakorn, C. Bacteremic Staphylococcus aureus Pneumonia. Scand. J. Infect. Dis. 1987, 19, 623-627. [CrossRef]

20. DeRyke, C.A.; Lodise, T.P.; Rybak, M.J.; McKinnon, P.S. Epidemiology, Treatment, and Outcomes of Nosocomial Bacteremic Staphylococcus aureus Pneumonia. Chest 2005, 128, 1414-1422. [CrossRef]

21. González, C.; Rubio, M.; Romero-Vivas, J.; González, M.; Picazo, J.J. Staphylococcus aureus bacteremic pneumonia: Differences between community and nosocomial acquisition. Int. J. Infect. Dis. IJID 2003, 7, 102-108. [CrossRef] 
22. De La Calle, C.; Morata, L.; Cobos-Trigueros, N.; Martinez, J.A.; Cardozo, C.; Mensa, J.; Soriano, A. Staphylococcus aureus bacteremic pneumonia. Eur. J. Clin. Microbiol. Infect. Dis. 2016, 35, 497-502. [CrossRef]

23. Sharov, K.S. SARS-CoV-2-related pneumonia cases in pneumonia picture in Russia in March-May 2020: Secondary bacterial pneumonia and viral co-infections. J. Glob. Health 2020, 10. [CrossRef]

24. Peacock, S.J.; Paterson, G.K. Mechanisms of Methicillin Resistance in Staphylococcus aureus. Annu. Rev. Biochem. 2015, 84, 577-601. [CrossRef]

25. Chambers, H.F.; DeLeo, F.R. Waves of resistance: Staphylococcus aureus in the antibiotic era. Nat. Rev. Genet. 2009, 7, 629-641. [CrossRef] [PubMed]

26. Fitzgerald, J.R. Livestock-associated Staphylococcus aureus: Origin, evolution and public health threat. Trends Microbiol. 2012, 20, 192-198. [CrossRef] [PubMed]

27. Nimmo, G. USA300 abroad: Global spread of a virulent strain of community-associated methicillin-resistant Staphylococcus aureus. Clin. Microbiol. Infect. 2012, 18, 725-734. [CrossRef]

28. Peng, H.; Liu, D.; Ma, Y.; Gao, W. Comparison of community- and healthcare-associated methicillin-resistant Staphylococcus aureus isolates at a Chinese tertiary hospital, 2012-2017. Sci. Rep. 2018, 8, 17916. [CrossRef] [PubMed]

29. Drougka, E.; Foka, A.; Liakopoulos, A.; Doudoulakakis, A.; Jelastopulu, E.; Chini, V.; Spiliopoulou, A.; Levidiotou, S.; Panagea, T.; Vogiatzi, A.; et al. A 12-year survey of methicillin-resistant Staphylococcus aureus infections in Greece: ST80-IV epidemic? Clin. Microbiol. Infect. 2014, 20, O796-O803. [CrossRef]

30. Lee, A.S.; De Lencastre, H.; Garau, J.; Kluytmans, J.; Malhotra-Kumar, S.; Peschel, A.; Harbarth, S. Methicillin-resistant Staphylococcus aureus. Nat. Rev. Dis. Prim. 2018, 4, 18033. [CrossRef]

31. International Working Group on the Classification of Staphylococcal Cassette Chromosome Elements (IWG-SCC). Classification of Staphylococcal Cassette Chromosome mec (SCCmec): Guidelines for Reporting Novel SCCmec Elements. Antimicrob. Agents Chemother. 2009, 53, 4961-4967. [CrossRef]

32. Foster, T.J. Antibiotic resistance in Staphylococcus aureus. Current status and future prospects. FEMS Microbiol. Rev. 2017, 41, 430-449. [CrossRef]

33. Jensen, S.O.; Lyon, B.R. Genetics of antimicrobial resistance in Staphylococcus aureus. Futur. Microbiol. 2009, 4, 565-582. [CrossRef]

34. Wang, X.; Li, X.; Liu, W.; Huang, W.; Fu, Q.; Li, M. Molecular Characteristic and Virulence Gene Profiles of Community-Associated Methicillin-Resistant Staphylococcus aureus Isolates from Pediatric Patients in Shanghai, China. Front. Microbiol. 2016, 7, 1818. [CrossRef]

35. Otto, M. Community-associated MRSA: What makes them special? Int. J. Med. Microbiol. 2013, 303, 324-330. [CrossRef] [PubMed]

36. Liu, G.Y. Molecular Pathogenesis of Staphylococcus aureus Infection. Pediatr. Res. 2009, 65, 71R-77R. [CrossRef]

37. Médecins Sans Frontières. Staphylococcal Pneumonia. In Clinical Guidelines_Diagnosis and Treatment Manual; Medecins Sans Frontieres: Geneva, Switzerland, 2020.

38. Fournier, B.; Philpott, D.J. Recognition of Staphylococcus aureus by the Innate Immune System. Clin. Microbiol. Rev. 2005, 18, 521-540. [CrossRef] [PubMed]

39. Parker, D.; Ryan, C.L.; Alonzo, F.; Torres, V.J.; Planet, P.J.; Prince, A.S. CD4+ T cells promote the pathogenesis of Staphylococcus aureus pneumonia. J. Infect. Dis. 2014, 211, 835-845. [CrossRef] [PubMed]

40. Spaan, A.N.; Surewaard, B.G.; Nijland, R.; Van Strijp, J.A.G. Neutrophils Versus Staphylococcus aureus: A Biological Tug of War. Annu. Rev. Microbiol. 2013, 67, 629-650. [CrossRef] [PubMed]

41. Shambat, S.M.; Chen, P.; Hoang, A.T.N.; Bergsten, H.; Vandenesch, F.; Siemens, N.; Lina, G.; Monk, I.R.; Foster, T.J.; Arakere, G.; et al. Modelling staphylococcal pneumonia in a human 3D lung tissue model system delineates toxin-mediated pathology. Dis. Model. Mech. 2015, 8, 1413-1425. [CrossRef]

42. Karauzum, H.; Datta, S.K. Adaptive Immunity against Staphylococcus aureus. Curr. Top. Microbiol. Immunol. 2016, 409, 419-439. [CrossRef]

43. Parker, D.; Prince, A. Immunopathogenesis of Staphylococcus aureus pulmonary infection. Semin. Immunopathol. 2012, 34, 281-297. [CrossRef]

44. Novick, R.P. Autoinduction and signal transduction in the regulation of staphylococcal virulence. Mol. Microbiol. 2003, 48, 1429-1449. [CrossRef] 
45. Vanhommerig, E.; Moons, P.; Pirici, D.; Lammens, C.; Hernalsteens, J.-P.; De Greve, H.; Kumar-Singh, S.; Goossens, H.; Malhotra-Kumar, S. Comparison of Biofilm Formation between Major Clonal Lineages of Methicillin Resistant Staphylococcus aureus. PLoS ONE 2014, 9, e104561. [CrossRef]

46. Kong, C.; Neoh,H.-M.; Nathan, S. Targeting Staphylococcus Aureus Toxins: A Potential form of Anti-Virulence Therapy. Toxins 2016, 8, 72. [CrossRef] [PubMed]

47. Tam, K.; Torres, V.J. Staphylococcus aureus Secreted Toxins and Extracellular Enzymes. Microbiol. Spectr. 2019, 7, 7. [CrossRef]

48. Kuroda, M.; Ohta, T.; Uchiyama, I.; Baba, T.; Yuzawa, H.; Kobayashi, I.; Cui, L.; Oguchi, A.; Aoki, K.-I.; Nagai, Y.; et al. Whole genome sequencing of meticillin-resistant Staphylococcus aureus. Lancet 2001, 357, 1225-1240. [CrossRef]

49. Baba, T.; Takeuchi, F.; Kuroda, M.; Yuzawa, H.; Aoki, K.-I.; Oguchi, A.; Nagai, Y.; Iwama, N.; Asano, K.; Naimi, T.; et al. Genome and virulence determinants of high virulence community-acquired MRSA. Lancet 2002, 359, 1819-1827. [CrossRef]

50. Lindsay, J.A. Hospital-associated MRSA and antibiotic resistance-What have we learned from genomics? Int. J. Med. Microbiol. 2013, 303, 318-323. [CrossRef]

51. Lindsay, J.A. Staphylococcus aureus genomics and the impact of horizontal gene transfer. Int. J. Med. Microbiol. 2014, 304, 103-109. [CrossRef]

52. Lindsay, J.A. Staphylococci: Evolving Genomes. Microbiol. Spectr. 2019, 7, 485-498. [CrossRef]

53. Fitzgerald, J.R.; Holden, M.T.G. Genomics of Natural Populations of Staphylococcus aureus. Annu. Rev. Microbiol. 2016, 70, 459-478. [CrossRef]

54. Surmann, K.; Simon, M.; Hildebrandt, P.; Pförtner, H.; Michalik, S.; Stentzel, S.; Steil, L.; Dhople, V.M.; Bernhardt, J.; Schlüter, R.; et al. A proteomic perspective of the interplay of Staphylococcus aureus and human alveolar epithelial cells during infection. J. Proteom. 2015, 128, 203-217. [CrossRef]

55. Richter, E.; Harms, M.; Ventz, K.; Nölker, R.; Fraunholz, M.J.; Mostertz, J.; Hochgräfe, F. Quantitative Proteomics Reveals the Dynamics of Protein Phosphorylation in Human Bronchial Epithelial Cells during Internalization, Phagosomal Escape, and Intracellular Replication of Staphylococcus aureus. J. Proteome Res. 2016, 15, 4369-4386. [CrossRef]

56. Michalik, S.; Depke, M.; Murr, A.; Salazar, M.G.; Kusebauch, U.; Sun, Z.; Meyer, T.C.; Surmann, K.; Pförtner, H.; Hildebrandt, P.; et al. A global Staphylococcus aureus proteome resource applied to the in vivo characterization of host-pathogen interactions. Sci. Rep. 2017, 7, 9718. [CrossRef] [PubMed]

57. Ventura, C.L.; Higdon, R.; Kolker, E.; Skerrett, S.J.; Rubens, C.E. Host Airway Proteins Interact with Staphylococcus aureus during Early Pneumonia. Infect. Immun. 2008, 76, 888-898. [CrossRef] [PubMed]

58. Prescott, M.A.; Pastey, M.K. Identification of Unique Blood and Urine Biomarkers in Influenza Virus and Staphylococcus aureus Co-infection: A Preliminary Study. Biomark. Insights 2010, 5, 145-151. [CrossRef] [PubMed]

59. Arshad, H.; Alfonso, J.C.L.; Franke, R.; Michaelis, K.; Araujo, L.; Habib, A.; Zboromyrska, Y.; Lücke, E.; Strungaru, E.; Akmatov, M.K.; et al. Decreased plasma phospholipid concentrations and increased acid sphingomyelinase activity are accurate biomarkers for community-acquired pneumonia. J. Transl. Med. 2019, 17, 1-18. [CrossRef] [PubMed]

60. Slupsky, C.M.; Cheypesh, A.; Chao, D.V.; Fu, H.; Rankin, K.N.; Marrie, T.J.; Lacy, P. Streptococcus pneumoniae and Staphylococcus aureus Pneumonia Induce Distinct Metabolic Responses. J. Proteome Res. 2009, 8, 3029-3036. [CrossRef] [PubMed]

61. Ambroggio, L.; Florin, T.A.; Shah, S.S.; Ruddy, R.; Yeomans, L.; Trexel, J.; Stringer, K.A. Emerging Biomarkers of Illness Severity: Urinary Metabolites Associated with Sepsis and Necrotizing Methicillin-Resistant Staphylococcus aureus Pneumonia. Pharmacother. J. Hum. Pharmacol. Drug Ther. 2017, 37, 1033-1042. [CrossRef]

62. Archer, N.K.; Mazaitis, M.J.; Costerton, J.W.; Leid, J.G.; Powers, M.E.; Shirtliff, M.E. Staphylococcus aureus biofilms. Virulence 2011, 2, 445-459. [CrossRef]

63. Otto, M. Staphylococcal Biofilms. Microbiol. Spectr. 2018, 6. [CrossRef]

64. Otto, M. Staphylococcal Biofilms. Curr. Top. Microbiol. Immunol. 2008, 322, 207-228.

65. Costerton, J.W.; Stewart, P.S.; Greenberg, E.P. Bacterial Biofilms: A Common Cause of Persistent Infections. Science 1999, 284, 1318-1322. [CrossRef] 
66. Parsek, M.R.; Singh, P.K. Bacterial Biofilms: An Emerging Link to Disease Pathogenesis. Annu. Rev. Microbiol. 2003, 57, 677-701. [CrossRef]

67. Wang, B.; Muir, T.W. Regulation of Virulence in Staphylococcus Aureus: Molecular Mechanisms and Remaining Puzzles. Cell Chem. Biol. 2016, 23, 214-224. [CrossRef]

68. Scherr, T.D.; Hanke, M.L.; Huang, O.; James, D.B.A.; Horswill, A.R.; Bayles, K.W.; Fey, P.D.; Torres, V.J.; Kielian, T. Staphylococcus aureus Biofilms Induce Macrophage Dysfunction Through Leukocidin AB and Alpha-Toxin. mBio 2015, 6, e01021-15. [CrossRef] [PubMed]

69. Den Reijer, P.M.; Haisma, E.M.; Lemmens-den Toom, N.A.; Willemse, J.; Koning, R.A.; Demmers, J.A.; Dekkers, D.H.; Rijkers, E.; El Ghalbzouri, A.; Nibbering, P.H.; et al. Detection of Alpha-Toxin and Other Virulence Factors in Biofilms of Staphylococcus aureus on Polystyrene and a Human Epidermal Model. PLoS ONE 2016, 11, e0145722. [CrossRef]

70. Lei, M.G.; Gupta, R.K.; Lee, C.Y. Proteomics of Staphylococcus aureus biofilm matrix in a rat model of orthopedic implant-associated infection. PLOS ONE 2017, 12, e0187981. [CrossRef] [PubMed]

71. Graf, A.C.; Leonard, A.; Schäuble, M.; Rieckmann, L.M.; Hoyer, J.; Maass, S.; Lalk, M.; Becher, D.; Pané-Farré, J.; Riedel, K. Virulence Factors Produced by Staphylococcus aureus Biofilms Have a Moonlighting Function Contributing to Biofilm Integrity. Mol. Cell. Proteom. 2019, 18, 1036-1053. [CrossRef] [PubMed]

72. Diep, B.A.; Hilliard, J.J.; Le, V.T.M.; Tkaczyk, C.; Le, H.N.; Tran, V.G.; Rao, R.L.; Dip, E.C.; Pereira-Franchi, E.P.; Cha, P.; et al. Targeting Alpha Toxin to Mitigate Its Lethal Toxicity in Ferret and Rabbit Models of Staphylococcus aureus Necrotizing Pneumonia. Antimicrob. Agents Chemother. 2017, 61, e2456-16. [CrossRef]

73. Anderson, M.J.; Lin, Y.-C.; Gillman, A.N.; Parks, P.J.; Schlievert, P.M.; Peterson, M.L. Alpha-Toxin Promotes Staphylococcus Aureus Mucosal Biofilm Formation. Front. Cell. Infect. Microbiol. 2012, 2, 64. [CrossRef]

74. Stulik, L.; Rouha, H.; Labrousse, D.; Visram, Z.C.; Badarau, A.; Maierhofer, B.; Groß, K.; Weber, S.; Kramarić, M.D.; Glojnarić, I.; et al. Preventing lung pathology and mortality in rabbit Staphylococcus aureus pneumonia models with cytotoxin-neutralizing monoclonal IgGs penetrating the epithelial lining fluid. Sci. Rep. 2019, 9, 5339. [CrossRef]

75. Hua, L.; Hilliard, J.J.; Shi, Y.; Tkaczyk, C.; Cheng, L.I.; Yu, X.; Datta, V.; Ren, S.; Feng, H.; Zinsou, R.; et al. Assessment of an Anti-Alpha-Toxin Monoclonal Antibody for Prevention and Treatment of Staphylococcus Aureus-Induced Pneumonia. Antimicrob. Agents Chemother. 2013, 58, 1108-1117. [CrossRef]

76. Wardenburg, J.B.; Schneewind, O. Vaccine protection against Staphylococcus aureus pneumonia. J. Exp. Med. 2008, 205, 287-294. [CrossRef]

77. Ragle, B.E.; Wardenburg, J.B. Anti-Alpha-Hemolysin Monoclonal Antibodies Mediate Protection against Staphylococcus aureus Pneumonia. Infect. Immun. 2009, 77, 2712-2718. [CrossRef]

78. Hua, L.; Cohen, T.S.; Shi, Y.; Datta, V.; Hilliard, J.J.; Tkaczyk, C.; Suzich, J.; Stover, C.K.; Sellman, B.R. MEDI4893* Promotes Survival and Extends the Antibiotic Treatment Window in a Staphylococcus aureus Immunocompromised Pneumonia Model. Antimicrob. Agents Chemother. 2015, 59, 4526-4532. [CrossRef] [PubMed]

79. Ruzin, A.; Yu, L.; Barraud, O.; François, B.; Garcia, M.S.; Eggimann, P.; Dequin, P.-F.; Laterre, P.-F.; Huberlant, V.; Viña, L.; et al. 2160. Performance of the Cepheid Rapid PCR Test for Patient Screening and Association with Efficacy of Suvratoxumab, A Novel Anti-Staphylococcus Aureus Monoclonal Antibody, During the Phase 2 SAATELLITE study. Open Forum Infect. Dis. 2019, 6, S733. [CrossRef]

80. François, B.; for the MASTER 1 Study Group; Mercier, E.; Gonzalez, C.; Asehnoune, K.; Nseir, S.; Fiancette, M.; Desachy, A.; Plantefève, G.; Meziani, F.; et al. Safety and tolerability of a single administration of AR-301, a human monoclonal antibody, in ICU patients with severe pneumonia caused by Staphylococcus aureus: First-in-human trial. Intensiv. Care Med. 2018, 44, 1787-1796. [CrossRef]

81. Magyarics, Z.; Provost, K.; Adi, N.; Czarnik, T.; Japaridze, K.; Kartsivadze, N.; Kirov, M.; Campanaro, E.; Muir, L.; Kollef, M.H.; et al. Results of a Phase 2, Randomized, Double-Blind, Placebo-Controlled Study to Determine the Safety and Efficacy of a Single Dose of the Monoclonal Antibody Combination ASN100 for the Prevention of Staphylococcus aureus Pneumonia in Endotracheal Heavily Colonized, Mechanically Ventilated Subjects. In Proceedings of the 29th Meeting of the European Society of Microbiology and Infectious Diseases (ECCMID), Amsterdam, The Netherlands, 13-16 April 2019.

82. Hayashida, A.; Bartlett, A.H.; Foster, T.J.; Park, P.W. Staphylococcus aureus Beta-Toxin Induces Lung Injury through Syndecan-1. Am. J. Pathol. 2009, 174, 509-518. [CrossRef] [PubMed] 
83. Zhou, Y.; Niu, C.; Ma, B.; Xue, X.; Li, Z.; Chen, Z.; Li, F.; Zhou, S.; Luo, X.; Hou, Z. Inhibiting PSM $\alpha$-induced neutrophil necroptosis protects mice with MRSA pneumonia by blocking the agr system. Cell Death Dis. 2018, 9, 1-14. [CrossRef] [PubMed]

84. Liu, Q.; Du, X.; Hong, X.; Li, T.; Zheng, B.; He, L.; Wang, Y.; Otto, M.; Li, M. Targeting Surface Protein SasX by Active and Passive Vaccination to Reduce Staphylococcus aureus Colonization and Infection. Infect. Immun. 2015, 83, 2168-2174. [CrossRef]

85. Wardenburg, J.B.; Bae, T.; Otto, M.; DeLeo, F.R.; Schneewind, O. Poring over pores: $\alpha$-hemolysin and Panton-Valentine leukocidin in Staphylococcus aureus pneumonia. Nat. Med. 2007, 13, 1405-1406. [CrossRef]

86. Tran, V.G.; Venkatasubramaniam, A.; Adhikari, R.P.; Krishnan, S.; Wang, X.; Le, V.T.M.; Le, H.N.; Vu, T.T.T.; Schneider-Smith, E.; Aman, M.J.; et al. Efficacy of Active Immunization with Attenuated $\alpha$-Hemolysin and Panton-Valentine Leukocidin in a Rabbit Model of Staphylococcus aureus Necrotizing Pneumonia. J. Infect. Dis. 2019, 221, 267-275. [CrossRef]

87. Diep, B.A.; Le, V.T.M.; Badiou, C.; Le, H.N.; Pinheiro, M.G.; Duong, A.H.; Wang, X.; Dip, E.C.; Aguiar-Alves, F.; Basuino, L.; et al. IVIG-mediated protection against necrotizing pneumonia caused by MRSA. Sci. Transl. Med. 2016, 8, 357ra124. [CrossRef] [PubMed]

88. Karauzum, H.; Adhikari, R.P.; Sarwar, J.; Devi, V.S.; Abaandou, L.; Haudenschild, C.; Mahmoudieh, M.; Boroun, A.R.; Vu, H.; Nguyen, T.; et al. Structurally Designed Attenuated Subunit Vaccines for S. aureus LukS-PV and LukF-PV Confer Protection in a Mouse Bacteremia Model. PLoS ONE 2013, 8, e65384. [CrossRef] [PubMed]

89. Poojary, N.S.; Ramlal, S.; Urs, R.M.; Murali, H.S.; Batra, H.V. Application of monoclonal antibodies generated against Panton-Valentine Leukocidin (PVL-S) toxin for specific identification of community acquired methicillin resistance Staphylococcus aureus. Microbiol. Res. 2014, 169, 924-930. [CrossRef] [PubMed]

90. Askarian, F.; Lapek, J.D.J.; Dongre, M.; Tsai, C.-M.; Kumaraswamy, M.; Kousha, A.; Valderrama, J.A.; Ludviksen, J.A.; Cavanagh, J.P.; Uchiyama, S.; et al. Staphylococcus aureus Membrane-Derived Vesicles Promote Bacterial Virulence and Confer Protective Immunity in Murine Infection Models. Front. Microbiol. 2018, 9, 262. [CrossRef]

91. Wang, X.; Thompson, C.D.; Weidenmaier, C.; Lee, J.C. Release of Staphylococcus aureus extracellular vesicles and their application as a vaccine platform. Nat. Commun. 2018, 9, 1-13. [CrossRef]

92. Choi, S.J.; Kim, M.-H.; Jeon, J.; Kim, O.Y.; Choi, Y.; Seo, J.; Hong, S.-W.; Lee, W.-H.; Jeon, S.G.; Gho, Y.S.; et al. Active Immunization with Extracellular Vesicles Derived from Staphylococcus aureus Effectively Protects against Staphylococcal Lung Infections, Mainly via Th1 Cell-Mediated Immunity. PLoS ONE 2015, 10, e0136021. [CrossRef]

93. Brown, L.; Wolf, J.M.; Prados-Rosales, R.; Casadevall, A. Through the wall: Extracellular vesicles in Gram-positive bacteria, mycobacteria and fungi. Nat. Rev. Genet. 2015, 13, 620-630. [CrossRef]

94. Wu, B.; Luo, J.-M.; Wang, Y.-H.; Shi, Y.-F.; Liu, H.; Ba, J.-H.; Zhang, T.-T. Inhibitory effects of simvastatin on staphylococcus aureus lipoteichoic acid-induced inflammation in human alveolar macrophages. Clin. Exp. Med. 2013, 14, 151-160. [CrossRef]

95. Hoogerwerf, J.J.; De Vos, A.F.; Bresser, P.; Van Der Zee, J.S.; Pater, J.M.; De Boer, A.; Tanck, M.; Lundell, D.L.; Her-Jenh, C.; Draing, C.; et al. Lung Inflammation Induced by Lipoteichoic Acid or Lipopolysaccharide in Humans. Am. J. Respir. Crit. Care Med. 2008, 178, 34-41. [CrossRef]

96. Leemans, J.C.; Heikens, M.; Van Kessel, K.P.M.; Florquin, S.; Van Der Poll, T. Lipoteichoic Acid and Peptidoglycan from Staphylococcus aureus Synergistically Induce Neutrophil Influx into the Lungs of Mice. Clin. Diagn. Lab. Immunol. 2003, 10, 950-953. [CrossRef]

97. Hoogerwerf, J.J.; De Vos, A.F.; Levi, M.; Bresser, P.; Van Der Zee, J.S.; Draing, C.; Von Aulock, S.; Van Der Poll, T. Activation of coagulation and inhibition of fibrinolysis in the human lung on bronchial instillation of lipoteichoic acid and lipopolysaccharide. Crit. Care Med. 2009, 37, 619-625. [CrossRef] [PubMed]

98. Yang, L.; Zhou, H.; Cheng, P.; Yang, Y.; Tong, Y.; Zuo, Q.; Feng, Q.; Zou, Q.-M.; Zeng, H. A novel bivalent fusion vaccine induces broad immunoprotection against Staphylococcus aureus infection in different murine models. Clin. Immunol. 2018, 188, 85-93. [CrossRef] [PubMed]

99. Thammavongsa, V.; Rauch, S.; Kim, H.K.; Missiakas, D.M.; Schneewind, O. Protein A-neutralizing monoclonal antibody protects neonatal mice against Staphylococcus aureus. Vaccine 2015, 33, 523-526. [CrossRef] [PubMed] 
100. Sun, Y.; Emolo, C.; Holtfreter, S.; Wiles, S.; Kreiswirth, B.; Missiakas, D.; Schneewind, O. Staphylococcal Protein A Contributes to Persistent Colonization of Mice with Staphylococcus aureus. J. Bacteriol. 2018, 200. [CrossRef]

101. Varshney, A.K.; Kuzmicheva, G.A.; Lin, J.; Bowling, R.A., Jr.; Sunley, K.M.; Kwan, T.-Y.; Mays, H.R.; Rambhadran, A.; Zhang, Y.; Martin, R.L.; et al. A natural human monoclonal antibody targeting Staphylococcus Protein A protects against Staphylococcus aureus bacteremia. PLoS ONE 2018, 13, e0190537. [CrossRef]

102. Huynh, T.; Stecher, M.; McKinnon, J.; Jung, N.; Rupp, M.E. Safety and Tolerability of 514G3, a True Human Anti-Protein A Monoclonal Antibody for the Treatment of S. aureus Bacteremia. Open Forum Infect. Dis. 2016, 3. [CrossRef]

103. Sharma-Kuinkel, B.K.; Tkaczyk, C.; Bonnell, J.; Yu, L.; Tovchigrechko, A.; Tabor, D.E.; Park, L.P.; Ruffin, F.; Esser, M.T.; Sellman, B.R.; et al. Associations of pathogen-specific and host-specific characteristics with disease outcome in patients with Staphylococcus aureus bacteremic pneumonia. Clin. Transl. Immunol. 2019, 8, e01070. [CrossRef]

104. Torres, V.J.; Attia, A.S.; Mason, W.J.; Hood, M.I.; Corbin, B.D.; Beasley, F.C.; Anderson, K.L.; Stauff, D.L.; McDonald, W.H.; Zimmerman, L.J.; et al. Staphylococcus aureus Fur Regulates the Expression of Virulence Factors That Contribute to the Pathogenesis of Pneumonia. Infect. Immun. 2010, 78, 1618-1628. [CrossRef]

105. Thomsen, I.P.; Sapparapu, G.; James, D.B.A.; Cassat, J.E.; Nagarsheth, M.; Kose, N.; Putnam, N.; Boguslawski, K.M.; Jones, L.S.; Wood, J.B.; et al. Monoclonal Antibodies Against the Staphylococcus aureus Bicomponent Leukotoxin AB Isolated Following Invasive Human Infection Reveal Diverse Binding and Modes of Action. J. Infect. Dis. 2017, 215, 1124-1131. [CrossRef]

106. Kailasan, S.; Kort, T.; Mukherjee, I.; Liao, G.C.; Kanipakala, T.; Williston, N.; Ganjbaksh, N.; Venkatasubramaniam, A.; Holtsberg, F.W.; Karauzum, H.; et al. Rational Design of Toxoid Vaccine Candidates for Staphylococcus aureus Leukocidin AB (LukAB). Toxins 2019, 11, 339. [CrossRef]

107. Wood, J.B.; Jones, L.S.; Soper, N.R.; Nagarsheth, M.; Creech, C.B.; Thomsen, I.P. Commercial Intravenous Immunoglobulin Preparations Contain Functional Neutralizing Antibodies against the Staphylococcus aureus Leukocidin LukAB (LukGH). Antimicrob. Agents Chemother. 2017, 61, 00968-17. [CrossRef] [PubMed]

108. Iii, F.A.; Kozhaya, L.; Rawlings, S.A.; Reyes-Robles, T.; Dumont, A.L.; Myszka, D.G.; Landau, N.R.; Unutmaz, D.; Torres, V.J. CCR5 is a receptor for Staphylococcus aureus leukotoxin ED. Nat. Cell Biol. 2013, 493, 51-55. [CrossRef]

109. Otto, M. Staphylococcus aureus toxins. Curr. Opin. Microbiol. 2014, 17, 32-37. [CrossRef] [PubMed]

110. Berube, B.J.; Wardenburg, J.B. Staphylococcus aureus $\alpha$-Toxin: Nearly a Century of Intrigue. Toxins 2013, 5, 1140-1166. [CrossRef] [PubMed]

111. Gouaux, E. $\alpha$-Hemolysin from Staphylococcus aureus: An Archetype of $\beta$-Barrel, Channel-Forming Toxins. J. Struct. Biol. 1998, 121, 110-122. [CrossRef]

112. Tavares, A.; Nielsen, J.B.; Boye, K.; Rohde, S.; Paulo, A.C.; Westh, H.; Schønning, K.; De Lencastre, H.; Miragaia, M. Insights into Alpha-Hemolysin (Hla) Evolution and Expression among Staphylococcus aureus Clones with Hospital and Community Origin. PLoS ONE 2014, 9, e98634. [CrossRef]

113. Tabor, D.E.; Yu, L.; Mok, H.; Tkaczyk, C.; Sellman, B.R.; Wu, Y.; Oganesyan, V.; Slidel, T.; Jafri, H.S.; McCarthy, M.; et al. Staphylococcus aureus Alpha-Toxin Is Conserved among Diverse Hospital Respiratory Isolates Collected from a Global Surveillance Study and Is Neutralized by Monoclonal Antibody MEDI4893. Antimicrob. Agents Chemother. 2016, 60, 5312-5321. [CrossRef]

114. Powers, M.E.; Kim, H.K.; Wang, Y.; Wardenburg, J.B. ADAM10 Mediates Vascular Injury Induced by Staphylococcus aureus $\alpha$-Hemolysin. J. Infect. Dis. 2012, 206, 352-356. [CrossRef]

115. Ragle, B.E.; Karginov, V.A.; Wardenburg, J.B. Prevention and Treatment of Staphylococcus aureus Pneumonia with a $\beta$-Cyclodextrin Derivative. Antimicrob. Agents Chemother. 2009, 54, 298-304. [CrossRef]

116. McElroy, M.C.; Harty, H.R.; Hosford, G.E.; Boylan, G.M.; Pittet, J.-F.; Foster, T.J. Alpha-Toxin Damages the Air-Blood Barrier of the Lung in a Rat Model of Staphylococcus Aureus-Induced Pneumonia. Infect. Immun. 1999, 67, 5541-5544. [CrossRef]

117. Wardenburg, J.B.; Patel, R.J.; Schneewind, O. Surface Proteins and Exotoxins Are Required for the Pathogenesis of Staphylococcus aureus Pneumonia. Infect. Immun. 2006, 75, 1040-1044. [CrossRef] [PubMed]

118. Caiazza, N.C.; O'Toole, G.A. Alpha-Toxin Is Required for Biofilm Formation by Staphylococcus aureus. J. Bacteriol. 2003, 185, 3214-3217. [CrossRef] [PubMed] 
119. Wang, Y.; Cheng, L.I.; Helfer, D.R.; Ashbaugh, A.G.; Miller, R.J.; Tzomides, A.J.; Thompson, J.M.; Ortines, R.V.; Tsai, A.S.; Liu, H.; et al. Mouse model of hematogenous implant-related Staphylococcus aureus biofilm infection reveals therapeutic targets. Proc. Natl. Acad. Sci. USA 2017, 114, E5094-E5102. [CrossRef] [PubMed]

120. Den Reijer, P.M.; Sandker, M.J.; Snijders, S.V.; Tavakol, M.; Hendrickx, A.P.; Van Wamel, W.J.B. Combining in vitro protein detection and in vivo antibody detection identifies potential vaccine targets against Staphylococcus aureus during osteomyelitis. Med. Microbiol. Immunol. 2016, 206, 11-22. [CrossRef]

121. Holtfreter, S.; Kolata, J.; Bröker, B.M. Towards the immune proteome of Staphylococcus aureus-The anti-S. aureus antibody response. Int. J. Med. Microbiol. 2010, 300, 176-192. [CrossRef] [PubMed]

122. Yu, K.O.A.; Randolph, A.G.; Agan, A.A.; Yip, W.-K.; Truemper, E.J.; Weiss, S.L.; Ackerman, K.G.; Schwarz, A.J.; Giuliano, J.S.; Hall, M.W.; et al. Staphylococcus aureus $\alpha$-Toxin Response Distinguishes Respiratory Virus-Methicillin-Resistant S. aureus Coinfection in Children. J. Infect. Dis. 2016, 214, 1638-1646. [CrossRef] [PubMed]

123. Karginov, V.A.; Nestorovich, E.M.; Schmidtmann, F.; Robinson, T.M.; Yohannes, A.; Fahmi, N.-E.; Bezrukov, S.M.; Hecht, S.M. Inhibition of S. aureus $\alpha$-hemolysin and B. anthracis lethal toxin by $\beta$-cyclodextrin derivatives. Bioorg. Med. Chem. 2007, 15, 5424-5431. [CrossRef]

124. Wang, J.; Zhou, X.; Liu, S.; Li, G.; Shi, L.; Dong, J.; Li, W.; Deng, X.; Niu, X. Morin hydrate attenuates Staphylococcus aureus virulence by inhibiting the self-assembly of $\alpha$-hemolysin. J. Appl. Microbiol. 2015, 118, 753-763. [CrossRef]

125. Jiang, L.; Yi, T.; Shen, Z.; Teng, Z.; Wang, J. Aloe-emodin Attenuates Staphylococcus aureus Pathogenicity by Interfering with the Oligomerization of $\alpha$-Toxin. Front. Cell. Infect. Microbiol. 2019, 9, 157. [CrossRef]

126. Dong, J.; Qiu, J.; Wang, J.; Li, H.; Dai, X.; Zhang, Y.; Wang, X.; Tan, W.; Niu, X.; Deng, X.; et al. Apigenin alleviates the symptoms of Staphylococcus aureus pneumonia by inhibiting the production of alpha-hemolysin. FEMS Microbiol. Lett. 2013, 338, 124-131. [CrossRef]

127. Lubkin, A.; Lee, W.L.; Alonzo, F.; Wang, C.; Aligo, J.; Keller, M.; Girgis, N.M.; Reyes-Robles, T.; Chan, R.; O'Malley, A.; et al. Staphylococcus aureus Leukocidins Target Endothelial DARC to Cause Lethality in Mice. Cell Host Microbe 2019, 25, 463-470.e9. [CrossRef] [PubMed]

128. Huseby, M.J.; Kruse, A.C.; Digre, J.; Kohler, P.L.; Vocke, J.A.; Mann, E.E.; Bayles, K.W.; Bohach, G.A.; Schlievert, P.M.; Ohlendorf, D.H.; et al. Beta toxin catalyzes formation of nucleoprotein matrix in staphylococcal biofilms. Proc. Natl. Acad. Sci. USA 2010, 107, 14407-14412. [CrossRef] [PubMed]

129. Herrera, A.; Vu, B.G.; Stach, C.S.; Merriman, J.A.; Horswill, A.R.; Salgado-Paboón, W.; Schlievert, P.M. Staphylococcus aureus $\beta$-Toxin Mutants Are Defective in Biofilm Ligase and Sphingomyelinase Activity, and Causation of Infective Endocarditis and Sepsis. Biochemistry 2016, 55, 2510-2517. [CrossRef] [PubMed]

130. Venkatasubramaniam, A.; Kanipakala, T.; Ganjbaksh, N.; Mehr, R.; Mukherjee, I.; Krishnan, S.; Bae, T.; Aman, M.J.; Adhikari, R. A Critical Role for HlgA in Staphylococcus aureus Pathogenesis Revealed by A Switch in the SaeRS Two-Component Regulatory System. Toxins 2018, 10, 377. [CrossRef]

131. Oliveira, D.; Borges, A.; Simões, M. Staphylococcus aureus Toxins and Their Molecular Activity in Infectious Diseases. Toxins 2018, 10, 252. [CrossRef]

132. Chatterjee, S.S.; Joo, H.-S.; Duong, A.C.; Dieringer, T.D.; Tan, V.Y.; Song, Y.; Fischer, E.R.; Cheung, G.Y.C.; Li, M.; Otto, M. Essential Staphylococcus aureus toxin export system. Nat. Med. 2013, 19, 364-367. [CrossRef]

133. Otto, M. Phenol-soluble modulins. Int. J. Med. Microbiol. 2014, 304, 164-169. [CrossRef]

134. Wang, R.; Braughton, K.R.; Kretschmer, D.; Bach, T.-H.L.; Queck, S.Y.; Li, M.; Kennedy, A.D.; Dorward, D.W.; Klebanoff, S.J.; Peschel, A.; et al. Identification of novel cytolytic peptides as key virulence determinants for community-associated MRSA. Nat. Med. 2007, 13, 1510-1514. [CrossRef]

135. Grosz, M.; Kolter, J.; Paprotka, K.; Winkler, A.-C.; Schäfer, D.; Chatterjee, S.S.; Geiger, T.; Wolz, C.; Ohlsen, K.; Otto, M.; et al. Cytoplasmic replication of Staphylococcus aureus upon phagosomal escape triggered by phenol-soluble modulin $\alpha$. Cell. Microbiol. 2014, 16, 451-465. [CrossRef]

136. Bloes, D.A.; Haasbach, E.; Hartmayer, C.; Hertlein, T.; Klingel, K.; Kretschmer, D.; Planz, O.; Peschel, A. Phenol-Soluble Modulin Peptides Contribute to Influenza A Virus-Associated Staphylococcus aureus Pneumonia. Infect. Immun. 2017, 85, e00620-17. [CrossRef]

137. Foster, T.J.; Geoghegan, J.A.; Ganesh, V.K.; Höök, M. Adhesion, invasion and evasion: The many functions of the surface proteins of Staphylococcus aureus. Nat. Rev. Genet. 2014, 12, 49-62. [CrossRef] [PubMed] 
138. Dayan, G.H.; Mohamed, N.; Scully, I.L.; Cooper, D.; Begier, E.; Eiden, J.; Jansen, K.; Gurtman, A.; Anderson, A.S.; Naglaa, M. Staphylococcus aureus: The current state of disease, pathophysiology and strategies for prevention. Expert Rev. Vaccines 2016, 15, 1373-1392. [CrossRef] [PubMed]

139. Ferry, T.; Perpoint, T.; Vandenesch, F.; Etienne, J. Virulence determinants in Staphylococcus aureus and their involvement in clinical syndromes. Curr. Infect. Dis. Rep. 2005, 7, 420-428. [CrossRef] [PubMed]

140. O’Neill, E.; Pozzi, C.; Houston, P.; Humphreys, H.; Robinson, D.A.; Loughman, A.; Foster, T.J.; O'Gara, J.P. A Novel Staphylococcus Aureus Biofilm Phenotype Mediated by the Fibronectin-Binding Proteins, FnBPA and FnBPB. J. Bacteriol. 2008, 190, 3835-3850. [CrossRef] [PubMed]

141. Raafat, D.; Otto, M.; Reppschläger, K.; Iqbal, J.; Holtfreter, S. Fighting Staphylococcus Aureus Biofilms with Monoclonal Antibodies. Trends Microbiol. 2019, 27, 303-322. [CrossRef]

142. Fowler, V.G.; Proctor, R.A. Where does a Staphylococcus aureus vaccine stand? Clin. Microbiol. Infect. 2014, 20, 66-75. [CrossRef]

143. Falugi, F.; Kim, H.K.; Missiakas, D.M.; Schneewind, O. Role of Protein A in the Evasion of Host Adaptive Immune Responses by Staphylococcus aureus. mBio 2013, 4, e00575-13. [CrossRef]

144. Gómez, M.I.; Lee, A.; Reddy, B.; Muir, A.; Soong, G.; Pitt, A.; Cheung, A.; Prince, A. Staphylococcus aureus protein A induces airway epithelial inflammatory responses by activating TNFR1. Nat. Med. 2004, 10, 842-848. [CrossRef]

145. Kim, H.K.; Cheng, A.G.; Kim, H.-Y.; Missiakas, D.M.; Schneewind, O. Nontoxigenic protein A vaccine for methicillin-resistant Staphylococcus aureus infections in mice. J. Exp. Med. 2010, 207, 1863-1870. [CrossRef]

146. Kim, H.K.; Emolo, C.; DeDent, A.C.; Falugi, F.; Missiakas, D.M.; Schneewind, O. Protein A-Specific Monoclonal Antibodies and Prevention of Staphylococcus aureus Disease in Mice. Infect. Immun. 2012, 80, 3460-3470. [CrossRef]

147. Foster, T.J. Surface Proteins of Staphylococcus aureus. Microbiol. Spectr. 2019, 7. [CrossRef] [PubMed]

148. Li, M.; Du, X.; Villaruz, A.E.; Diep, B.A.; Wang, D.; Song, Y.; Tian, Y.; Hu, J.; Yu, F.; Lu, Y.; et al. MRSA epidemic linked to a quickly spreading colonization and virulence determinant. Nat. Med. 2012, 18, 816-819. [CrossRef]

149. Holden, M.T.G.; Lindsay, J.A.; Corton, C.; Quail, M.A.; Cockfield, J.D.; Pathak, S.; Batra, R.; Parkhill, J.; Bentley, S.D.; Edgeworth, J.D. Genome Sequence of a Recently Emerged, Highly Transmissible, Multi-Antibiotic- and Antiseptic-Resistant Variant of Methicillin-Resistant Staphylococcus aureus, Sequence Type 239 (TW). J. Bacteriol. 2010, 192, 888-892. [CrossRef] [PubMed]

150. Otto, M. How colonization factors are linked to outbreaks of methicillin-resistant Staphylococcus aureus: The roles of SasX and ACME. Biomol. Concepts 2013, 4, 533-537. [CrossRef]

151. Mazmanian, S.K.; Liu, G.; Jensen, E.R.; Lenoy, E.; Schneewind, O. Staphylococcus aureus sortase mutants defective in the display of surface proteins and in the pathogenesis of animal infections. Proc. Natl. Acad. Sci. USA 2000, 97, 5510-5515. [CrossRef]

152. Mazmanian, S.K.; Ton-That, H.; Su, K.; Schneewind, O. An iron-regulated sortase anchors a class of surface protein during Staphylococcus aureus pathogenesis. Proc. Natl. Acad. Sci. USA 2002, 99, 2293-2298. [CrossRef] [PubMed]

153. Clancy, K.W.; Melvin, J.A.; McCafferty, D.G. Sortase transpeptidases: Insights into mechanism, substrate specificity, and inhibition. Biopolymers 2010, 94, 385-396. [CrossRef]

154. Wang, G.; Gao, Y.; Wang, H.; Niu, X.; Wang, J. Baicalin Weakens Staphylococcus aureus Pathogenicity by Targeting Sortase B. Front. Cell. Infect. Microbiol. 2018, 8, 418. [CrossRef]

155. Cascioferro, S.; Cusimano, M.G.; Schillaci, D. Antiadhesion agents against Gram-positive pathogens. Futur. Microbiol. 2014, 9, 1209-1220. [CrossRef]

156. Maresso, A.W.; Schneewind, O. Sortase as a Target of Anti-Infective Therapy. Pharmacol. Rev. 2008, 60, 128-141. [CrossRef]

157. Ou, Y.; He, X.; Yuan, Z.; Yin, Z.; Fu, H.; Lin, J.; He, C.; Liang, X.-X.; Lv, C.; Shu, G.; et al. Erianin against Staphylococcus aureus Infection via Inhibiting Sortase A. Toxins 2018, 10, 385. [CrossRef]

158. Yoong, P.; Torres, V.J. The effects of Staphylococcus aureus leukotoxins on the host: Cell lysis and beyond. Curr. Opin. Microbiol. 2013, 16, 63-69. [CrossRef] [PubMed]

159. Lina, G.; Piémont, Y.; Godail-Gamot, F.; Bes, M.; Peter, M.-O.; Gauduchon, V.; Vandenesch, F.; Etienne, J. Involvement of Panton-Valentine Leukocidin-Producing Staphylococcus aureus in Primary Skin Infections and Pneumonia. Clin. Infect. Dis. 1999, 29, 1128-1132. [CrossRef] [PubMed] 
160. Perret, M.; Badiou, C.; Lina, G.; Burbaud, S.; Benito, Y.; Bes, M.; Cottin, V.; Couzon, F.; Juruj, C.; Dauwalder, O.; et al. Cross-talk between Staphylococcus aureus leukocidins-intoxicated macrophages and lung epithelial cells triggers chemokine secretion in an inflammasome-dependent manner. Cell. Microbiol. 2012, 14, 1019-1036. [CrossRef]

161. Peng, Z.; Takeshita, M.; Shibata, N.; Tada, H.; Tanaka, Y.; Kaneko, J. Rim domain loops of staphylococcal $\beta$-pore forming bi-component toxin S-components recognize target human erythrocytes in a coordinated manner. J. Biochem. 2018, 164, 93-102. [CrossRef]

162. Li, H.-T.; Zhang, T.-T.; Huang, J.; Zhou, Y.-Q.; Zhu, J.-X.; Wu, B.-Q. Factors Associated with the Outcome of Life-Threatening Necrotizing Pneumonia due to Community-Acquired Staphylococcus aureus in Adult and Adolescent Patients. Respir. Int. Rev. Thorac. Dis. 2010, 81, 448-460. [CrossRef]

163. Vandenesch, F.; Couzon, F.; Boisset, S.; Benito, Y.; Brown, E.L.; Lina, G.; Etienne, J.; Bowden, M.G. The Panton-Valentine leukocidin is a virulence factor in a murine model of necrotizing pneumonia. J. Infect. Dis. 2010, 201, 967-969. [CrossRef]

164. Takigawa, Y.; Fujiwara, K.; Saito, T.; Nakasuka, T.; Ozeki, T.; Okawa, S.; Takada, K.; Iwamoto, Y.; Kayatani, H.; Minami, D.; et al. Rapidly Progressive Multiple Cavity Formation in Necrotizing Pneumonia Caused by Community-acquired Methicillin-resistant Staphylococcus aureus Positive for the Panton-Valentine Leucocidin Gene. Int. Med. 2019, 58, 685-691. [CrossRef]

165. Mosquera, M.; Montero, L.; Pérez-Lescure, F.J.; Aragón, A. Pediatric case of fatal necrotizing pneumonia due to Panton-Valentine leukocidin-positive methicillin-resistant Staphylococcus aureus in Spain. Enferm. Infecc. Microbiol. Clínica 2019, 37, 63. [CrossRef]

166. Schwartz, K.L.; Nourse, C. Panton-Valentine leukocidin-associated Staphylococcus aureus necrotizing pneumonia in infants: A report of four cases and review of the literature. Eur. J. Nucl. Med. Mol. Imaging 2011, 171, 711-717. [CrossRef]

167. Löffler, B.; Niemann, S.; Ehrhardt, C.; Horn, D.; Lanckohr, C.; Lina, G.; Ludwig, S.; Peters, G. Pathogenesis of Staphylococcus aureus necrotizing pneumonia: The role of PVL and an influenza coinfection. Expert Rev. Anti. Infect. Ther. 2013, 11, 1041-1051. [CrossRef] [PubMed]

168. Shallcross, L.J.; Fragaszy, E.; Johnson, A.M.; Hayward, A.C. The role of the Panton-Valentine leucocidin toxin in staphylococcal disease: A systematic review and meta-analysis. Lancet Infect. Dis. 2013, 13, 43-54. [CrossRef]

169. Rouzic, N.; Janvier, F.; Libert, N.; Javouhey, E.; Lina, G.; Nizou, J.-Y.; Pasquier, P.; Stamm, D.; Brinquin, L.; Pelletier, C.; et al. Prompt and Successful Toxin-Targeting Treatment of Three Patients with Necrotizing Pneumonia Due to Staphylococcus aureus Strains Carrying the Panton-Valentine Leukocidin Genes. J. Clin. Microbiol. 2010, 48, 1952-1955. [CrossRef]

170. Soavi, L.; Signorini, L.; Stellini, R.; Acquarolo, A.; Fiorese, B.; Magri, S.; Pantosti, A.; Suter, F.; Carori, G. Linezolid and clindamycin improve the outcome of severe, necrotizing pneumonia due to community-acquired methicillin-resistant Staphylococcus aureus (CA-MRSA). Le Infez. Med. 2011, 19, $42-44$.

171. Croisier, D.; Hayez, D.; Da Silva, S.; Labrousse, D.; Biek, D.; Badiou, C.; Dumitrescu, O.; Guerard, P.; Charles, P.-E.; Piroth, L.; et al. In VivoEfficacy of Ceftaroline Fosamil in a Methicillin-Resistant Panton-Valentine Leukocidin-Producing Staphylococcus aureus Rabbit Pneumonia Model. Antimicrob. Agents Chemother. 2014, 58, 1855-1861. [CrossRef] [PubMed]

172. Dinarello, C.A. Blocking interleukin-1 $\beta$ in acute and chronic autoinflammatory diseases. J. Intern. Med. 2011, 269, 16-28. [CrossRef] [PubMed]

173. Labrousse, D.; Perret, M.; Hayez, D.; Da Silva, S.; Badiou, C.; Couzon, F.; Bes, M.; Chavanet, P.; Lina, G.; Vandenesch, F.; et al. Kineret@/IL-1ra Blocks the IL-1/IL-8 Inflammatory Cascade during Recombinant Panton Valentine Leukocidin-Triggered Pneumonia but Not during S. aureus Infection. PLoS ONE 2014, 9, e97546. [CrossRef]

174. Lee, E.-Y.; Choi, D.-Y.; Kim, D.-K.; Kim, J.-W.; Park, J.O.; Kim, S.; Kim, S.-H.; Desiderio, D.M.; Kim, Y.-K.; Kim, K.P.; et al. Gram-positive bacteria produce membrane vesicles: Proteomics-based characterization of Staphylococcus aureus-derived membrane vesicles. Proteomics 2009, 9, 5425-5436. [CrossRef]

175. Neuhaus, F.C.; Baddiley, J. A Continuum of Anionic Charge: Structures and Functions of d-Alanyl-Teichoic Acids in Gram-Positive Bacteria. Microbiol. Mol. Biol. Rev. 2003, 67, 686-723. [CrossRef]

176. Akira, S.; Uematsu, S.; Takeuchi, O. Pathogen Recognition and Innate Immunity. Cell 2006, 124, $783-801$. [CrossRef] 
177. Beutler, B.; Jiang, Z.; Georgel, P.; Crozat, K.; Croker, B.; Rutschmann, S.; Du, X.; Hoebe, K. GENETIC ANALYSIS OF HOST RESISTANCE: Toll-Like Receptor Signaling and Immunity at Large. Annu. Rev. Immunol. 2006, 24, 353-389. [CrossRef] [PubMed]

178. Goldblatt, D. Conjugate vaccines. Clin. Exp. Immunol. 2000, 119, 1-3. [CrossRef] [PubMed]

179. Yi, X.-Y.; Huang, Z.-X.; Hou, X.-R.; Zhu, P.; Wang, X.-Y.; Luo, H.-B.; Liu, B.-Y. Immunization with a peptide mimicking Lipoteichoic acid protects mice against Staphylococcus aureus infection. Vaccine 2019, 37, 4325-4335. [CrossRef] [PubMed]

180. Dumont, A.L.; Nygaard, T.K.; Watkins, R.L.; Smith, A.; Kozhaya, L.; Kreiswirth, B.N.; Shopsin, B.; Unutmaz, D.; Voyich, J.M.; Torres, V.J. Characterization of a new cytotoxin that contributes to Staphylococcus aureus pathogenesis. Mol. Microbiol. 2011, 79, 814-825. [CrossRef]

181. Berends, E.T.M.; Zheng, X.; Zwack, E.E.; Ménager, M.M.; Cammer, M.; Shopsin, B.; Torres, V.J. Staphylococcus aureus Impairs the Function of and Kills Human Dendritic Cells via the LukAB Toxin. mBio 2019, 10, e01918-18. [CrossRef] [PubMed]

182. Malachowa, N.; Kobayashi, S.D.; Freedman, B.; Dorward, D.W.; DeLeo, F.R. Staphylococcus aureus Leukotoxin GH Promotes Formation of Neutrophil Extracellular Traps. J. Immunol. 2013, 191, 6022-6029. [CrossRef] [PubMed]

183. Nocadello, S.; Minasov, G.; Shuvalova, L.; Dubrovska, I.; Sabini, E.; Bagnoli, F.; Grandi, G.; Anderson, W.F. Crystal structures of the components of the Staphylococcus aureus leukotoxin ED. Acta Crystallogr. Sect. D Struct. Biol. 2016, 72, 113-120. [CrossRef] [PubMed]

184. Seilie, E.S.; Wardenburg, J.B. Staphylococcus aureus pore-forming toxins: The interface of pathogen and host complexity. Semin. Cell Dev. Biol. 2017, 72, 101-116. [CrossRef]

185. Iii, F.A.; Benson, M.A.; Chen, J.; Novick, R.P.; Shopsin, B.; Torres, V.J. Staphylococcus aureus leucocidin ED contributes to systemic infection by targeting neutrophils and promoting bacterial growth in vivo. Mol. Microbiol. 2012, 83, 423-435. [CrossRef]

186. Tam, K.; Schultz, M.; Reyes-Robles, T.; Vanwalscappel, B.; Horton, J.; Alonzo, F.; Wu, B.; Landau, N.R.; Torres, V.J. Staphylococcus aureus Leukocidin LukED and HIV-1 gp120 Target Different Sequence Determinants on CCR5. mBio 2016, 7, e02024-16. [CrossRef]

187. Fillat, M.F. The FUR (ferric uptake regulator) superfamily: Diversity and versatility of key transcriptional regulators. Arch. Biochem. Biophys. 2014, 546, 41-52. [CrossRef] [PubMed]

188. Troxell, B.; Hassan, H.M. Transcriptional regulation by Ferric Uptake Regulator (Fur) in pathogenic bacteria. Front. Cell. Infect. Microbiol. 2013, 3, 59. [CrossRef] [PubMed]

189. Bagnoli, F.; Fontana, M.R.; Soldaini, E.; Mishra, R.P.N.; Fiaschi, L.; Cartocci, E.; Nardi-Dei, V.; Ruggiero, P.; Nosari, S.; De Falco, M.G.; et al. Vaccine composition formulated with a novel TLR7-dependent adjuvant induces high and broad protection against Staphylococcus aureus. Proc. Natl. Acad. Sci. USA 2015, 112, 3680-3685. [CrossRef] [PubMed]

190. Proctor, R.A. Challenges for a Universal Staphylococcus aureus Vaccine. Clin. Infect. Dis. 2012, 54, 1179-1186. [CrossRef]

191. Jansen, K.U.; Anderson, A.S. The role of vaccines in fighting antimicrobial resistance (AMR). Hum. Vaccines Immunother. 2018, 14, 2142-2149. [CrossRef]

192. Miller, L.S.; Fowler, V.G.; Shukla, S.K.; Rose, W.E.; A Proctor, R. Development of a vaccine against Staphylococcus aureus invasive infections: Evidence based on human immunity, genetics and bacterial evasion mechanisms. FEMS Microbiol. Rev. 2020, 44, 123-153. [CrossRef]

193. Rouha, H.; Badarau, A.; Visram, Z.C.; Battles, M.B.; Prinz, B.; Magyarics, Z.; Nagy, G.; Mirkina, I.; Stulik, L.; Zerbs, M.; et al. Five birds, one stone: Neutralization of $\alpha$-hemolysin and 4 bi-component leukocidins of Staphylococcus aureus with a single human monoclonal antibody. mAbs 2015, 7, 243-254. [CrossRef]

194. Diep, B.A.; Le, V.T.M.; Visram, Z.C.; Rouha, H.; Stulik, L.; Dip, E.C.; Nagy, G.; Nagy, E. Improved Protection in a Rabbit Model of Community-Associated Methicillin-Resistant Staphylococcus aureus Necrotizing Pneumonia upon Neutralization of Leukocidins in Addition to Alpha-Hemolysin. Antimicrob. Agents Chemother. 2016, 60, 6333-6340. [CrossRef]

195. Vu, T.T.T.; Nguyen, N.T.Q.; Tran, V.G.; Gras, E.; Mao, Y.; Jung, D.H.; Tkaczyk, C.; Sellman, B.R.; Diep, B.A. Protective Efficacy of Monoclonal Antibodies Neutralizing Alpha-Hemolysin and Bicomponent Leukocidins in a Rabbit Model of Staphylococcus aureus Necrotizing Pneumonia. Antimicrob. Agents Chemother. 2019, 64. [CrossRef] 
196. Rouha, H.; Weber, S.; Janesch, P.; Maierhofer, B.; Gross, K.; Dolezilkova, I.; Mirkina, I.; Visram, Z.C.; Malafa, S.; Stulik, L.; et al. Disarming Staphylococcus aureus from destroying human cells by simultaneously neutralizing six cytotoxins with two human monoclonal antibodies. Virulence 2017, 9, 231-247. [CrossRef]

197. Adhikari, R.P.; Karauzum, H.; Sarwar, J.; Abaandou, L.; Mahmoudieh, M.; Boroun, A.R.; Vu, H.; Nguyen, T.; Devi, V.S.; Shulenin, S.; et al. Novel Structurally Designed Vaccine for S. aureus $\alpha$-Hemolysin: Protection against Bacteremia and Pneumonia. PLoS ONE 2012, 7, e38567. [CrossRef] [PubMed]

198. CARB-X. IBT-VO2. Available online: https://carb-X.org/gallery/integrated-biotherapeutics/ (accessed on 11 August 2020).

199. Wolfmeier, H.; Mansour, S.C.; Liu, L.T.; Pletzer, D.; Draeger, A.; Babiychuk, E.B.; Hancock, R.E. Liposomal Therapy Attenuates Dermonecrosis Induced by Community-Associated Methicillin-Resistant Staphylococcus aureus by Targeting $\alpha$-Type Phenol-Soluble Modulins and $\alpha$-Hemolysin. EBioMedicine 2018, 33, 211-217. [CrossRef] [PubMed]

200. Chan, R.; Buckley, P.T.; O’Malley, A.; Sause, W.E.; Alonzo, F.; Lubkin, A.; Boguslawski, K.M.; Payne, A.; Fernandez, J.; Strohl, W.R.; et al. Identification of biologic agents to neutralize the bicomponent leukocidins of Staphylococcus aureus. Sci. Transl. Med. 2019, 11, eaat0882. [CrossRef]

201. Adhikari, R.; Kort, T.; Shulenin, S.; Kanipakala, T.; Ganjbaksh, N.; Roghmann, M.-C.; Holtsberg, F.W.; Aman, M.J. Antibodies to S. aureus LukS-PV Attenuated Subunit Vaccine Neutralize a Broad Spectrum of Canonical and Non-Canonical Bicomponent Leukotoxin Pairs. PLoS ONE 2015, 10, e0137874. [CrossRef]

202. Song, L.; Hobaugh, M.R.; Shustak, C.; Cheley, S.; Bayley, H.; Gouaux, J.E. Structure of Staphylococcal alpha -Hemolysin, a Heptameric Transmembrane Pore. Science 1996, 274, 1859-1865. [CrossRef] [PubMed]

203. Yamashita, K.; Kawai, Y.; Tanaka, Y.; Hirano, N.; Kaneko, J.; Tomita, N.; Ohta, M.; Kamio, Y.; Yao, M.; Tanaka, I. Crystal structure of the octameric pore of staphylococcal -hemolysin reveals the -barrel pore formation mechanism by two components. Proc. Natl. Acad. Sci. USA 2011, 108, 17314-17319. [CrossRef]

204. Trstenjak, N.; Milić, D.; Graewert, M.A.; Rouha, H.; Svergun, D.; Djinović-Carugo, K.; Nagy, E.; Badarau, A. Molecular mechanism of leukocidin GH-integrin CD11b/CD18 recognition and species specificity. Proc. Natl. Acad. Sci. USA 2019, 117, 317-327. [CrossRef]

205. Pédelacq, J.-D.; Maveyraud, L.; Prévost, G.; Baba-Moussa, L.; González, A.; Courcelle, E.; Shepard, W.; Monteil, H.; Samama, J.-P.; Mourey, L. The structure of a Staphylococcus aureus leucocidin component (LukF-PV) reveals the fold of the water-soluble species of a family of transmembrane pore-forming toxins. Structure 1999, 7, 277-287. [CrossRef]

206. IBT Inc. IBT Vaccines Receives $\$ 3.9$ mil. to Advance Development of IBT-V02, the First Multivalent Toxoid Vaccine for MRSA. Available online: https://www.integratedbiotherapeutics.com/2019/ibt-vaccines-receives3-9-mil-to-advance-development-of-ibt-v02-the-first-multivalent-toxoid-vaccine-for-mrsa/ (accessed on 11 August 2020).

207. Berube, B.J.; Sampedro, G.R.; Otto, M.; Wardenburg, J.B. Thepsm $\alpha$ Locus Regulates Production of Staphylococcus aureus Alpha-Toxin during Infection. Infect. Immun. 2014, 82, 3350-3358. [CrossRef]

208. Jenul, C.; Horswill, A.R. Regulation of Staphylococcus aureus Virulence. Microbiol. Spectr. 2019, 7, 6. [CrossRef]

209. François, B.; Jafri, H.S.; Chastre, J.; Sánchez-García, M.; Eggimann, P.; Dequin, P.-F.; Huberlant, V.; Soria, L.V.; Boulain, T.; Bretonnière, C.; et al. Suvratoxumab for Prevention of Staphylococcus aureus Ventilator-Associated Pneumonia. (In Preparation)

210. Malachowa, N.; Kobayashi, S.D.; Braughton, K.R.; Whitney, A.R.; Parnell, M.J.; Gardner, D.J.; DeLeo, F.R. Staphylococcus aureus Leukotoxin GH Promotes Inflammation. J. Infect. Dis. 2012, 206, 1185-1193. [CrossRef] [PubMed]

211. Dumont, A.L.; Yoong, P.; Day, C.J.; Alonzo, F.; McDonald, W.H.; Jennings, M.P.; Torres, V.J. Staphylococcus aureus LukAB cytotoxin kills human neutrophils by targeting the CD11b subunit of the integrin Mac-1. Proc. Natl. Acad. Sci. USA 2013, 110, 10794-10799. [CrossRef] [PubMed]

212. Prince, A.; Wang, H.; Kitur, K.; Parker, D. Humanized Mice Exhibit Increased Susceptibility to Staphylococcus aureus Pneumonia. J. Infect. Dis. 2016, 215, 1386-1395. [CrossRef]

213. Holtfreter, S.; Radcliff, F.J.; Grumann, D.; Read, H.; Johnson, S.; Monecke, S.; Ritchie, S.; Clow, F.; Goerke, C.; Bröker, B.M.; et al. Characterization of a Mouse-Adapted Staphylococcus aureus Strain. PLoS ONE 2013, 8, e71142. [CrossRef] 
214. Trübe, P.; Hertlein, T.; Mrochen, D.M.; Schulz, D.; Jorde, I.; Krause, B.; Zeun, J.; Fischer, S.; Wolf, S.A.; Walther, B.; et al. Bringing together what belongs together: Optimizing murine infection models by using mouse-adapted Staphylococcus aureus strains. Int. J. Med. Microbiol. 2019, 309, 26-38. [CrossRef]

215. Trstenjak, N.; Stulik, L.; Rouha, H.; Zmajkovic, J.; Zerbs, M.; Nagy, E.; Badarau, A. Adaptation of the Staphylococcus aureus leukocidin LukGH for the rabbit host by protein engineering. Biochem. J. 2019, 476, 275-292. [CrossRef]

216. Takemura-Uchiyama, I.; Uchiyama, J.; Osanai, M.; Morimoto, N.; Asagiri, T.; Ujihara, T.; Daibata, M.; Sugiura, T.; Matsuzaki, S. Experimental phage therapy against lethal lung-derived septicemia caused by Staphylococcus aureus in mice. Microbes Infect. 2014, 16, 512-517. [CrossRef]

217. Prazak, J.; Iten, M.; Cameron, D.R.; Save, J.; Grandgirard, D.; Resch, G.; Goepfert, C.; Leib, S.L.; Takala, J.; Jakob, S.M.; et al. Bacteriophages Improve Outcomes in Experimental Staphylococcus aureus Ventilator-associated Pneumonia. Am. J. Respir. Crit. Care Med. 2019, 200, 1126-1133. [CrossRef]

218. Prazak, J.; Valente, L.; Iten, M.; Grandgirard, D.; Leib, S.L.; Jakob, S.M.; Haenggi, M.; Que, Y.-A.; Cameron, D.R. Nebulized Bacteriophages for Prophylaxis of Experimental Ventilator-Associated Pneumonia Due to Methicillin-Resistant Staphylococcus aureus. Crit. Care Med. 2020, 48, 1042-1046. [CrossRef]

219. Lehman, S.M.; Mearns, G.; Rankin, D.; Cole, R.A.; Smrekar, F.; Branston, S.D.; Morales, S. Design and Preclinical Development of a Phage Product for the Treatment of Antibiotic-Resistant Staphylococcus aureus Infections. Viruses 2019, 11, 88. [CrossRef]

220. Ooi, M.L.; Drilling, A.J.; Morales, S.; Fong, S.; Moraitis, S.; Macias-Valle, L.; Vreugde, S.; Psaltis, A.J.; Wormald, P.-J. Safety and Tolerability of Bacteriophage Therapy for Chronic Rhinosinusitis Due to Staphylococcus aureus. JAMA Otolaryngol. Neck Surg. 2019, 145, 723-729. [CrossRef]

221. Petrovic, F.A.; Lin, R.C.Y.; Ho, J.; Maddocks, S.; Zankour, B.N.L.; Iredell, J.R.; Khalid, A.; Venturini, C.; Chad, R.; Morales, S.; et al. Safety of bacteriophage therapy in severe Staphylococcus aureus infection. Nat. Microbiol. 2020, 5, 465-472. [CrossRef] [PubMed]

222. Xia, F.; Li, X.; Wang, B.; Gong, P.; Xiao, F.; Yang, M.; Zhang, L.; Songying, O.; Hu, L.; Cheng, M.; et al. Combination Therapy of LysGH15 and Apigenin as a New Strategy for Treating Pneumonia Caused by Staphylococcus aureus. Appl. Environ. Microbiol. 2016, 82, 87-94. [CrossRef] [PubMed]

223. Bae, J.Y.; Jun, K.I.; Kang, C.K.; Song, K.-H.; Choe, P.G.; Bang, J.-H.; Kim, E.S.; Park, S.W.; Bin Kim, H.; Kim, N.J.; et al. Efficacy of Intranasal Administration of the Recombinant Endolysin SAL200 in a Lethal Murine Staphylococcus Aureus Pneumonia Model. Antimicrob. Agents Chemother. 2019, 63, 02009-02018. [CrossRef]

224. Nilsson, A.S. Pharmacological limitations of phage therapy. Upsala J. Med. Sci. 2019, 124, 218-227. [CrossRef] [PubMed]

225. Irene, C.; Fantappiè, L.; Caproni, E.; Zerbini, F.; Anesi, A.; Tomasi, M.; Zanella, I.; Stupia, S.; Prete, S.; Valensin, S.; et al. Bacterial outer membrane vesicles engineered with lipidated antigens as a platform for Staphylococcus aureus vaccine. Proc. Natl. Acad. Sci. USA 2019, 116, 21780-21788. [CrossRef]

Publisher's Note: MDPI stays neutral with regard to jurisdictional claims in published maps and institutional affiliations.

(C) 2020 by the authors. Licensee MDPI, Basel, Switzerland. This article is an open access article distributed under the terms and conditions of the Creative Commons Attribution (CC BY) license (http://creativecommons.org/licenses/by/4.0/). 